High I evel s of inorgani $c$ ar seni $c$ in rice in ar eas where ar seni c-cont ami nat ed water is used for i rrigati on and cooking

\begin{tabular}{|l|l|}
\hline 著者 & Rahman M Azi zur, Hasegawa Hi r oshi \\
\hline $\begin{array}{l}\text { j our nal or } \\
\text { publ i cat i on t i t l e }\end{array}$ & Sci ence of the Tot al Envi r onment \\
\hline vol une & 409 \\
\hline number & 22 \\
\hline page r ange & $4645-4655$ \\
\hline year & 2011- 10-15 \\
\hline URL & ht t p: //hdl . handl e. net /2297/29477 \\
\hline
\end{tabular}




\section{High Levels of Inorganic Arsenic in Rice in Areas where Arsenic- Contaminated Water is Used for Irrigation and Cooking}

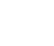

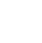

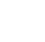

${ }^{1}$ Graduate School of Natural Science and Technology, Kanazawa University, Kakuma, Kanazawa 920-1192, Japan

${ }^{2}$ Centre for Environmental Sustainability, School of the Environment, Faculty of Science, University of Technology Sydney, P.O. Box 123, Broadway, NSW 2007, Australia

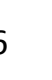

17

18

19

\section{*Corresponding author}

E-mail: Mohammad.Rahman@uts.edu.au rahmanmazizur@gmail.com 


\section{Abstract}

Rice is the staple food for the people of arsenic endemic South (S) and South-East (SE) Asian countries. In this region, arsenic contaminated groundwater has been used not only for drinking and cooking purposes but also for rice cultivation during dry season. Irrigation of arsenic-contaminated groundwater for rice cultivation has resulted high deposition of arsenic in topsoil and uptake in rice grain posing a serious threat to the sustainable agriculture in this region. In addition, cooking rice with arsenic-contaminated water also increases arsenic burden in cooked rice. Inorganic arsenic is the main species of S and SE Asian rice (80 to 91\% of the total arsenic), and the concentration of this toxic species is increased in cooked rice from inorganic arsenic-rich cooking water. The people of Bangladesh and West Bengal (India), the arsenic hot spots in the world, eat an average of 450 g rice a day. Therefore, in addition to drinking water, dietary intake of arsenic from rice is supposed to be another potential source of exposure, and to be a new disaster for the population of S and SE Asian countries. Arsenic speciation in raw and cooked rice, its bioavailability and the possible health hazard of inorganic arsenic in rice for the population of S and SE Asia have been discussed in this review.

Keywords: Arsenic, Rice, Dietary intake, Inorganic arsenic. 


\section{Introduction}

Arsenic is the $20^{\text {th }}$ abundant element in earth crust, and is ubiquitous in the environment (soil, water, air and in living matters) (Tamaki and Frankenberger, 1992). It has been well recognized that consumption of arsenic-contaminated foods leads to carcinogenesis (Mandal and Suzuki, 2002). Chronic effects of arsenic toxicity on humans have been reported from most of the countries in South (S) and South-East (SE) Asia through its widespread water and crop contamination (Kohnhorst, 2005; Mukherjee et al., 2006; Smedley, 2005). Arsenic contaminated groundwater is used not only for drinking purpose but also for crop irrigation, particularly for the paddy rice (Oryza sativa L.), in S and SE Asian countries (Meharg and Rahman, 2003; Ninno and Dorosh, 2001). In Bangladesh, arsenic-contaminated groundwater has been used extensively to irrigate paddy rice, particularly during the dry season, with $75 \%$ of the total cropped area given to rice cultivation (Meharg and Rahman, 2003). Background levels of arsenic in rice paddy soils range from 4 to $8 \mu \mathrm{g} \mathrm{g}^{-1}$ (Alam and Sattar, 2000; Williams et al., 2006), which can reach up to $83 \mu \mathrm{g} \mathrm{g}^{-1}$ in areas where the crop land has been irrigated with arsenic-contaminated groundwater (Williams et al., 2006). The problem of arsenic contamination in groundwater is not just restricted to Bangladesh. Other countries in S and SE Asia such as West Bengal (India), Vietnam, Thailand, Nepal and Taiwan have also been reported to have high levels of arsenic in groundwater (Dahal et al., 2008; Nordstrom, 2002) (Fig. 1). Paddy rice is the staple food for the people of these regions. Increasing levels of arsenic in agricultural soils from contaminated underground irrigation water, and its uptake in rice, vegetables, and other food crops (Meharg and Rahman, 2003; Williams et al., 2006) has become a real health emergency in this region. The presence of high levels of arsenic in rice is supposed to be a health disaster in South Asia 
(Meharg, 2004). Around 200 million people in S and SE Asia is supposed to be exposed to arsenic contamination from water and foods(Sun et al., 2006).

A large population in Asian arsenic endemic areas lives on subsistence diet of rice, a cereal which is grown mainly with groundwater contaminated by high level of arsenic. Therefore, rice contains relatively higher amount of arsenic, most of which is inorganic (Meharg et al., 2009; Sun et al., 2008; Torres-Escribano et al., 2008), compared to other agricultural products (Das et al., 2004; Schoof et al., 1999). The concentration of arsenic and its chemical forms in rice vary considerably depending on rice variety (Booth, 2008) and geographical variation (Booth, 2007; Meharg et al., 2009). The inorganic arsenic species dominates over organoarsenic species in both raw and cooked rice (Williams et al., 2005), which is accumulated/absorbed from paddy soil, irrigation water, and cooking water. Therefore, arsenic speciation in rice grain is influenced by its speciation in soil and water. In addition, the amount of arsenic absorbed by the cooked rice from cooking water and, the dietary intake of arsenic in human body are depended on the type of rice and the way the rice is cooked (Musaiger and D'Souza, 2008; Ohno et al., 2009; Rahman et al., 2006; Signes et al., 2008a; Signes et al., 2008b). Considering the high concentration of arsenic (mainly inorganic arsenic) in rice grain, cooking method, and high consumption rate, rice is revealed to be a major threat to health of the people of arsenic endemic S and SE Asian countries. In this review, arsenic speciation in rice, dietary intake, and health risk of inorganic arsenic species to the arsenic endemic and rice subsistent population of S and SE Asian countries have been discussed.

\section{Arsenic in irrigation water: A threat to sustainable rice cultivation in $S$ and} SE Asia 
The problem of arsenic contamination in groundwater is now well recognized in most of the $\mathrm{S}$ and SE Asian countries as discussed in the previous sections. Rice is the main cereal crop produced in this region, especially in Bangladesh and West Bengal (India), which is irrigated with groundwater during dry season. Recently, it has become apparent that arsenic-contaminated irrigation water is adding significant amount of arsenic in the topsoil and in rice, which pose serious threat to sustainable rice cultivation in these two countries (Brammer and Ravenscroft, 2009; Dittmar et al., 2010; Khan et al., 2009; Khan et al., 2010a; Khan et al., 2010b; Meharg and Rahman, 2003). Since the agroecological and hydrogeological conditions of the S and SE Asian countries are broadly similar, irrigation of arsenic-contaminated groundwater is supposed to produce similar effects on paddy rice of this region. In addition, paddy rice is considered to be one of the major and potential exposure sources of arsenic for humans (Meharg and Rahman, 2003; Mondal and Polya, 2008; Pillai et al., 2010; Rahman et al., 2008a; Singh et al., 2010; Tuli et al., 2010; Williams et al., 2006; Zavala and Duxbury, 2008) because of its increasing deposition in the topsoil from irrigation water and its subsequent uptake in rice grain (Dittmar et al., 2010).

Irrigation with arsenic-contaminated groundwater may particularly affect rice cultivation in terms of production and contamination. There may be two main reasons for this- i) a large amount of underground water containing high level of arsenic has been irrigated for rice cultivation in most parts of S and SE Asia during dry season and ii) rice is the crop that is most susceptible to arsenic toxicity (Brammer and Ravenscroft, 2009). Due to the decrease of rainfall in this region, even in monsoon season, the dependency on groundwater for rice cultivation is expected to be increased in the coming years in order to increase crop production to meet the demands of the increasing population. This practice will increase additional arsenic deposition in 
topsoil. Roberts et al. (2007) reported that arsenic contents in topsoil in Bangladesh have increased significantly over the last 15 years because of irrigation with arsenic-rich groundwater. Other studies showed that arsenic concentrations remain unchanged at the start of two successive irrigation seasons suggesting that arsenic added during the first irrigation season had been leached by floodwater during the following monsoon season (Dittmar et al., 2007). Thus, the rate of arsenic deposition from contaminated irrigation water would be higher in flat terrain soil than that in floodland soil.

Another important concern regarding arsenic deposition in paddy soil is whether all arsenic delivered by the tube wells is reached and deposited throughout the fields equally. In addition, how arsenic in irrigation water and soil contributes to its uptake in rice plant and grain is also important concern. Brammer and Ravenscroft (2009) discussed these issues in a recent review on arsenic in S and SE Asia perspective. They urged that groundwater of most arsenicaffected areas in S and SE Asia is rich in iron (Gurung et al., 2005; Postma et al., 2007), which is oxidized upon exposure to the air, and is then precipitated as iron-hydroxides in the rhizosphere. Arsenate has high binding affinity to these precipitated iron-hydroxides. Therefore, arsenic concentration in soil is decreased with increasing distance of the location from the well-head (Dittmar et al., 2007; Roberts et al., 2007). But being an important nutrient, iron precipitation decreases its bioavailability and uptake resulting iron-chlorosis in rice plant. In such conditions, farmers use iron-fertilizers to increase iron bioavailability and uptake to correct iron-chlorosis (Alvarez-Fernandez et al., 2005; Hasegawa et al., 2010; Hasegawa et al., 2011). Since arsenic is adsorbed on precipitated iron-hydroxides in the rhizosphere soil, application of iron-fertilizer may increase both iron and arsenic bioavailability and uptake in rice plant (Hasegawa et al., 2011; Rahman et al., 2008b). In addition to iron fertilizer, rhizospheric microbes also solubilise 
ferric iron in the rhizosphere by exuding siderophores to the root-plaque interface (Bar-Ness et al., 1992; Crowley et al., 1992; Crowley et al., 1991; Kraemer, 2004; Romheld, 1987), which may also render both iron and arsenic bioavailable and uptake in rice plant. Being the strategy II plant, rice roots also exude phytosiderophores in the rhizosphere soil under iron-deficient condition to increase iron bioavailability and uptake (Ishimaru et al., 2006; Romheld and Marschner, 1986). In this case, there is also a possibility of the increase of arsenic bioavailability to and uptake in rice plant. The rice cultivation conditions also favour arsenic uptake in rice plant. Rice is grown in flooded (anaerobic) conditions in which arsenic exists mainly as dissolve As(III) form and is readily taken up from the soil solution by rice plant (Xu et al., 2008).

The arsenic uptake mechanisms in rice is more complicated because of its ability to carry oxygen from the air down to its stem and discharge it in the rhizosphere through the roots (Brammer and Ravenscroft, 2009). This creates an oxidized zone around the roots in which iron is oxidized and precipitated to forms a coating (Liu et al., 2006). Hu et al. (2007) found that sulfur enhances the formation of iron plaque in the rhizosphere and reduces arsenic accumulation in rice. In another study, Hu et al. (2005) observed that the use of phosphate fertilizer decreased iron-plaque formation on rice roots. Although the formation of iron-coating on rice root surface should increase arsenic adsorption, and thus act as an arsenic filter, some studies showed that significant amount of arsenic is taken up by rice plants in this condition too (Meharg and Rahman, 2003).

\section{Arsenic concentration and speciation in raw rice}

\subsection{Arsenic in raw rice}


Up to date, significant number of articles on arsenic concentrations in rice and in its

162

163

164

165 fractions have been published (Bae et al., 2002; Meharg, 2004; Mondal et al., 2010; Mondal and Polya, 2008; Rahman et al., 2006; Rahman et al., 2007a; Rahman et al., 2008a; Williams et al., 2006; Williams et al., 2005; Williams et al., 2007b). This implies that the dietary intake of arsenic form rice has been received much attention to understand the fat of arsenic exposure. Rice is by far the largest dietary source $(50-70 \%$ of the total meal) of arsenic for rural populations even where drinking water does not contain elevated levels of arsenic (Chatterjee et al., 2010). About ten-fold elevation of arsenic in Bangladeshi rice has been reported (Meharg and Rahman, 2003). Arsenic concentrations in rice grain from different countries are shown in Table 1, which provide useful information to have an idea about the range of arsenic concentration in rice worldwide, and to predict the extent of possible dietary intake of arsenic from this food source.

Recently, high arsenic content in S and SE Asian rice is an important concern for the respective countries as well as for the countries which import rice from this region. Rice grain collected from arsenic-contaminated western part of Bangladesh had arsenic levels of 0.03-1.84 $\mu \mathrm{g} \mathrm{g}^{-1}$ dry weight (d. wt.) (Meharg and Rahman, 2003). Williams et al. (2006) reported that arsenic level ranged between 0.04 and $0.92 \mu \mathrm{g} \mathrm{g}^{-1} \mathrm{~d}$. wt. (mean 0.08-0.36 $\mu \mathrm{g} \mathrm{g} \mathrm{g}^{-1} \mathrm{~d}$. wt.) in aman (dry season) rice and between 0.04 and $0.91 \mu \mathrm{g} \mathrm{g}^{-1} \mathrm{~d}$. wt. (mean 0.14-0.51 $\mathrm{gg} \mathrm{g}^{-1} \mathrm{~d}$. wt.) in boro (monsoon season) rice collected from southern part of the country (Table 1). In the same study, arsenic concentrations in aman and boro rice collected from markets across the country were found to be $0.18-0.31$ and $0.21-0.27 \mu g^{-1} \mathrm{~d}$. wt., respectively. These findings were in consistent with their previous study. Islam et al. (2004) found 0.05-2.05 $\mu \mathrm{g} \mathrm{g}^{-1} \mathrm{~d}$. wt. of arsenic in boro rice collected from three districts of southern Bangladesh (Gopalganj, Rajbari, and Faridpur). 
Rahman et al. (2006) also reported high level of arsenic in raw rice (0.57-0.69 $\mu \mathrm{g} \mathrm{g}^{-1} \mathrm{~d}$. wt.) collected from Satkhira district, a highly arsenic-contaminated area in Bangladesh. All these studies reveal the subsistence of high arsenic in Bangladeshi raw rice.

Total arsenic concentrations in Indian rice, particularly from West Bengal, have been reported in a number of articles (Table 1). Williams et al. (2005) reported $0.05 \mu \mathrm{g} \mathrm{g}^{-1} \mathrm{~d}$. wt.

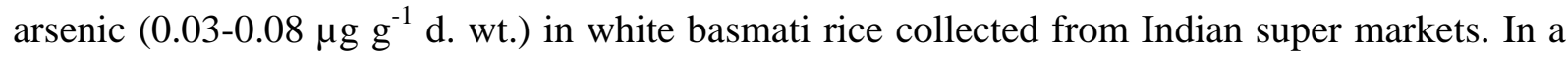
market basket survey, Meharg et al. (2009) found $0.07 \mu \mathrm{g} \mathrm{g}^{-1} \mathrm{~d}$. wt. arsenic (0.07-0.31 $\mu \mathrm{g} \mathrm{g}^{-1} \mathrm{~d}$. wt., $n=133$ ) in Indian white rice. Mondal and Polya (2008) investigated arsenic concentration in rice from some areas of Nadia district, West Bengal. They found that the mean concentration of arsenic in raw rice (the rice were either collected directly from farmers or purchased from local markets) ranged between 0.02 and $0.17 \mu \mathrm{g} \mathrm{g}^{-1} \mathrm{~d}$. wt. with a mean of $0.13 \mu \mathrm{g} \mathrm{g}^{-1} \mathrm{~d}$. wt. $(n=50)$. This concentration was comparable to that in Bangladeshi rice $\left(0.14 \mu \mathrm{g} \mathrm{g}^{-1}\right.$ d. wt., $\left.n=10\right)$ reported by Das et al. (2004), but was less than that reported by Williams et al. (2006) (0.08 to $0.51 \mu \mathrm{g} \mathrm{g}^{-1}$ d. wt., $\left.n=330\right)$ and Ohno et al. (2007) $\left(0.34 \mu \mathrm{g} \mathrm{g}^{-1} \mathrm{~d}\right.$. wt., $\left.n=18\right)$. Other studies also reported high level of arsenic in raw rice from West Bengal (0.11-0.44 $\mu \mathrm{g} \mathrm{g}^{-1} \mathrm{~d}$. wt. by Roychowdhury et al. (2002) and 0.03-0.48 $\mu \mathrm{g} \mathrm{g}^{-1} \mathrm{~d}$. wt. by Pal et al. (2009)).

Arsenic contamination in Taiwan has a long history, and a number of studies reveal high level of arsenic in Taiwanese rice. Schoof et al. (1998) reported $0.76 \mu \mathrm{g} \mathrm{g}^{-1} \mathrm{~d}$. wt. of arsenic in Taiwanese rice collected directly from farms. They also reported about $0.20 \mu \mathrm{g} \mathrm{g}^{-1} \mathrm{~d}$. wt. of arsenic (range 0.19-0.22 $\mu \mathrm{g} \mathrm{g}^{-1} \mathrm{~d}$. wt.) in Taiwanese firm rice. A market basket survey, conducted by Lin et al. (2004) revealed $<0.10-0.63 \mu \mathrm{g} \mathrm{g}^{-1} \mathrm{~d}$. wt. of arsenic in Taiwanese rice, which is comparable to that reported by Williams et al. (2005). The concentration of arsenic in 
Vietnamese rice was found to be 0.03-0.47 $\mu \mathrm{g} \mathrm{g}^{-1} \mathrm{~d}$. wt. (Phuong et al., 1999; Williams et al., 2005).

Thai rice has also been reported to contain high level of arsenic (Table 1). A recent market basket survey revealed that arsenic concentrations in Thai rice ranged between 0.01 and $0.39 \mu \mathrm{g} \mathrm{g}^{-1} \mathrm{~d}$. wt. with a mean of $0.14 \mu \mathrm{g} \mathrm{g}^{-1} \mathrm{~d}$. wt. $(n=54)$ (Meharg et al., 2009). Previously, Williams et al. (2005) reported $0.11 \pm 0.01 \mu \mathrm{g} \mathrm{g}^{-1} \mathrm{~d}$. wt. of arsenic in Thai rice. In another study of Williams et al. (2006) showed that the concentration of arsenic in Thai rice was $0.10 \mu \mathrm{g} \mathrm{g}^{-1} \mathrm{~d}$. wt. (range 0.06-0.14 $\mu \mathrm{g} \mathrm{g}^{-1} \mathrm{~d}$. wt.). Compared to the previous reports of Williams et al. (2006; 2005), higher arsenic concentration in Thai rice was found in a recent study of Meharg et al. (2009) suggesting that arsenic levels in Thai rice have increased in recent years. Significant amount of arsenic was also found in rice from United States of America (USA). A market basket survey conducted by Schoof et al. (1999) reported that the total arsenic concentrations in USA rice was 0.20-0.46 $\mu \mathrm{g} \mathrm{g}^{-1} \mathrm{~d}$. wt., while Heitkemper et al. (2001) found 0.11-0.34 $\mu g \mathrm{~g}^{-1} \mathrm{~d}$. wt. in rice of the country. A recent study of Meharg et al. (2009) reported 0.03-0.66 $\mu \mathrm{g} \mathrm{g}^{-1} \mathrm{~d}$. wt. in USA rice, which is much higher than that reported by Williams et al. (2005) (0.11-0.40 $\mu \mathrm{g} \mathrm{g}^{-1} \mathrm{~d}$. wt.) (Table 1). All these studies reveal that arsenic concentration in Asian rice is higher than that of other countries. Thus, S and SE Asian rice would be a significant source of dietary arsenic for the population of this area, and also for the population of those countries that import rice from this region.

\subsubsection{Variations in total arsenic concentration in raw rice}

Arsenic concentrations in raw rice varied significantly with its origin, types and cultivars, and even with the growing seasons (Table 1 and 2). Geographical variations in total arsenic 
concentration in rice have been found from market basket surveys in USA, European Union (EU), Japan, Philippines, Australia, China, Canada, and from S and SE Asian countries (Table 1). A recent study conducted by Meharg et al. (2009) showed the geographical variations in total and inorganic arsenic concentrations in rice. The EU rice had a mean arsenic level of $0.18 \mu \mathrm{g} \mathrm{g}^{-1}$ d. wt. ranging from 0.13 to $0.22 \mu \mathrm{g} \mathrm{g}^{-1} \mathrm{~d}$. wt. (Torres-Escribano et al., 2008). In another study, Williams et al. (2005) reported 0.13-0.20 $\mu \mathrm{g} \mathrm{g}^{-1} \mathrm{~d}$. wt. of total arsenic in EU rice. Arsenic concentration in rice from some districts of arsenic affected areas of West Bengal, India showed variations ranging between 0.04 and $0.43 \mu \mathrm{g} \mathrm{g}^{-1} \mathrm{~d}$. wt. Other studies also reported the variations of total arsenic concentration in rice for other geographical areas such as Australia (0.02-0.03 $\mu \mathrm{g}$ $\mathrm{g}^{-1}$ d. wt. (Williams et al., 2006)), Canada (0.02-0.11 $\mu \mathrm{g} \mathrm{g}^{-1}$ d. wt. (Heitkemper et al., 2001; Williams et al., 2005)), China (0.02-0.46 $\mu g \mathrm{~g}^{-1} \mathrm{~d}$. wt. (Meharg et al., 2009); 0.07-0.19 $\mu \mathrm{g} \mathrm{g} \mathrm{g}^{-1} \mathrm{~d}$. wt. (Williams et al., 2006); 0.46-1.18 $\mu \mathrm{g} \mathrm{g}^{-1}$ d. wt. (Sun et al., 2008)), Egypt (0.01-0.58 $\mu g \mathrm{~g}^{-1} \mathrm{~d}$. wt. (Meharg et al., 2009)), Europe (0.09-0.56 $\mu \mathrm{g} \mathrm{g}^{-1}$ d. wt. (Meharg et al., 2009)), Spain (0.05$0.82 \mu g^{-1}$ d. wt. (Meharg et al., 2009)), Japan (0.07-0.42 $\mu g^{-1}$ d. wt. (Meharg et al., 2009)), and Philippines (0.00-0.25 $\mu \mathrm{g} \mathrm{g}^{-1} \mathrm{~d}$. wt. (Williams et al., 2006)). These studies reveal that Australian, Philippians, and Canadian rice have the lowest total arsenic burden while Bangladeshi and Indian (West Bengal) rice have the highest burden. Taiwanese and Vietnamese rice also contain significant amount of arsenic. These variations were clearly correlated with the extent and type of pollution as well as with the rice cultivation methods. Soil chemistry, source of arsenic, arsenic concentrations in soil and geochemistry of the region also influence arsenic burden in rice.

Arsenic concentrations in rice also vary by region within a particular geographical area. The USA rice showed significant variations in total arsenic concentration by region (Booth, 
2007). A market basket survey of arsenic in USA rice by Williams et al. (2007a) showed that rice from California contains, on average, about $40 \%$ less arsenic than that from the south central USA- Arkansas, Louisiana, Mississippi, Texas, and Missouri. This is supposed to be because the soils of south central USA contained higher arsenic from pesticides used to grow cotton (Booth, 2008). Although arsenic concentrations in rice varied significantly for arsenic-contaminated and non-contaminated areas in Bangladesh and West Bengal, a uniform range of its concentration in rice was observed in contaminated areas of this region. Arsenic concentrations in raw rice were found to be significantly correlated $(P<0.001)$ with its concentrations in irrigation water and soil (Pal et al., 2009). High arsenic concentrations in raw rice of arsenic endemic south Asian countries is the direct contribution of highly contaminated underground irrigation water and paddy soils rather than the other sources.

Meharg and Rahman (2003) also found variations in arsenic concentration in different rice varieties grown in Bangladesh Rice Research Institute’s research station (between 0.043 and $0.206 \mu \mathrm{g} \mathrm{g}^{-1} \mathrm{~d}$. wt.) and in those collected from different district of the country (between 0.058 and $1.835 \mu \mathrm{g} \mathrm{g}^{-1} \mathrm{~d}$. wt.). Seasonal variations in arsenic concentrations in Bangladeshi rice have also been reported by Duxbury et al. (2003). Arsenic concentrations in aman and boro rice were found to be $0.11(n=72)$ and $0.18(n=78) \mu \mathrm{g} \mathrm{g}^{-1} \mathrm{~d}$. wt., respectively.

\subsubsection{Distribution of arsenic in different fractions of raw rice}

Significant variations in total arsenic concentrations in different fractions of raw rice (hull, endosperm, polished rice, whole rice, and bran) have been reported in literature. Rahman et al. (2007b) studied total arsenic concentrations in different fractions of parboiled and non-parboiled raw rice collected from arsenic-contaminated area (Satkhira district) of Bangladesh. Results 
showed that arsenic concentrations in non-parboiled raw rice were significantly higher than those in parboiled rice. The highest arsenic concentrations were in husk (in the range of 0.7-1.6 $\mu \mathrm{g} \mathrm{g}^{-1}$ d. wt.) followed by bran (0.6-1.2 $\mu \mathrm{g} \mathrm{g}^{-1} \mathrm{~d}$. wt.), whole grain (0.5-0.8 $\mu \mathrm{g} \mathrm{g}^{-1} \mathrm{~d}$. wt.), and polished rice (0.3-0.5 $\mu \mathrm{g} \mathrm{g}^{-1} \mathrm{~d}$. wt.). Thus, the order of arsenic concentrations in rice fractions was husk > bran $>$ whole rice $>$ polish rice. Ren et al. (2007) also determined the total arsenic concentration in fractions of Chinese whole grain rice, and found that arsenic concentrations were highest in bran (in the range of $0.55-1.20 \mu \mathrm{g} \mathrm{g}^{-1} \mathrm{~d}$. wt.), followed by whole grain $\left(0.14-0.80 \mu \mathrm{g} \mathrm{g}^{-1} \mathrm{~d}\right.$. wt.) and polished rice (0.07-0.4 $\mu \mathrm{g} \mathrm{g}^{-1} \mathrm{~d}$. wt.), showing the same trend reported by Rahman et al. (2007b). Sun et al. (2008) also determined total arsenic concentrations in different fractions (endosperm, whole grain, and bran) of freshly milled Chinese (two varieties) and Bangladeshi (four varieties) rice grains. Results showed that the mean $(n=6)$ arsenic concentrations in endosperm, whole grain, and bran were $0.56 \pm 0.08,0.76 \pm 0.12$, and $3.3 \pm 0.6 \mu \mathrm{g} \mathrm{g}^{-1} \mathrm{~d}$. wt., respectively. The trend of total arsenic concentration in fractions of rice grain was endosperm < whole grain < bran, which is in consistent with the previous studies of Rahman et al. (2007b) and Ren et al. (2007).

\subsection{Arsenic speciation in raw rice}

Total arsenic concentrations in rice or in any other diets are not the only determinant of its toxicity. Arsenic toxicity mostly depends on its speciation, and inorganic arsenic species is more toxic than organoarsenicals (Meharg and Hartley Whitaker, 2002; Ng, 2005). More specifically, A(III) is more toxic than As(V), while dimethylarsinous acid (DMAA(III)) and monomethylarsonous acid (MMAA(III)) are more toxic than their parent compounds (Mass et al., 2001; Petrick et al., 2000). Rice is particularly susceptible to arsenic accumulation compared to 
other cereals as it is generally grown under flooded (reduced) conditions where arsenic mobility is high (Zhu et al., 2008b). Baseline level of arsenic in rice is up to 10-fold higher than that in other cereal grains (Williams et al., 2007b). On average, around 50\% of total arsenic in rice grain is inorganic arsenic, which can vary from 10 to $90 \%$, and the remaining fractions are DMAA(V) with trace amounts of MMAA(V) is some samples (Zhu et al., 2008b). Therefore, arsenic speciation in rice is considered to be important for its possible impacts on human health.

\subsubsection{Inorganic arsenic species}

Arsenic speciation in raw rice from different geographical areas is shown in Table 1. With exception for USA rice, inorganic arsenic have been reported to be the main species in raw rice from other geographical areas around the world (Booth, 2008; Meharg et al., 2009; Potera, 2007; Schoof et al., 1999; Signes-Pastor et al., 2008; Sun et al., 2008; Sun et al., 2009; Williams et al., 2006; Williams et al., 2005; Zhu et al., 2008a; Zhu et al., 2008b). Although As(III) predominates over $\mathrm{As}(\mathrm{V})$ in rice in most cases (Williams et al., 2005; Zavala et al., 2008), the ratio of arsenic species in rice showed significant inconsistency with origin, types and varieties (Meharg et al., 2009; Williams et al., 2005). Williams et al. (2005) reported that about 42 ( $n=$ 12), $64(n=7), 80(n=11)$, and $81 \%(n=15)$ of the recovered arsenic was found to be inorganic for USA, EU, Bangladeshi, and Indian rice, respectively. A number of studies revealed that about $44-86 \%$ of the total arsenic concentration in Bangladeshi rice is inorganic (Meharg et al., 2009; Sun et al., 2008; Williams et al., 2006; Williams et al., 2005). In a field study, Ohno et al. (2007) found up to 100\% inorganic arsenic in Bangladeshi rice. Schoof et al. (1998) reported 61, 58, and $67 \%$ of the total arsenic to be inorganic in Taiwanese rice, while about $91 \%$ was inorganic in Thai rice (Williams et al., 2005). Chinese rice concentration about $60-87 \%$ inorganic 
arsenic (Meharg et al., 2009; Sun et al., 2008), while the per cent concentration of inorganic arsenic species in France and Italian rice were about 44-62\% and 57-73\% (Meharg et al., 2009; Williams et al., 2005). Spanish rice also contains higher percentage of inorganic arsenic (about 41-48\% of the total arsenic) (Laparra et al., 2005; Williams et al., 2005), but was less than that in France and Italian rice. The fraction of inorganic arsenic in USA rice was about $40 \%$ of the total concentration, which is the lowest compared to that in rice from other countries. The results reveal that except for USA, the highly toxic inorganic arsenic species is the predominant species in rice. Other studies also showed that USA rice mostly contained less toxic methylated species where as EU and Asian rice contained more toxic inorganic arsenic (Zavala and Duxbury, 2008; Zavala et al., 2008).

\subsubsection{Organoarsenic species}

Methylated species of arsenic are the only organoarsenic species that were found in rice. Williams et al. (2005) conducted a market basket survey on arsenic speciation in USA rice and found methylated arsenicals (almost entirely as DMAA(V)) to be the major species (between 36$65 \%$ with a mean of 54\% of the total arsenic). Previously, Heitkemper et al. (2001) also reported much higher percentage of methylated arsenicals (DMAA(V); between $70-80 \%$ with a mean of $64 \%$ of the total arsenic) in USA rice. In contrast, methylated arsenicals were found to be the minor species in rice from Bangladesh (12-43\%) (Sun et al., 2008; Williams et al., 2005), Canada (9-50\%) (Heitkemper et al., 2001; Williams et al., 2005), China (10-15\%) (Sun et al., 2008), EU (30\%) (Williams et al., 2005), India (12\%) (Williams et al., 2005), Italy (26-40\%) (Williams et al., 2005), Spain (29\%) (Williams et al., 2005), Thailand (27\%) (Williams et al., 2005), and Taiwan (14-25\%) (Schoof et al., 1998). The variations in organoarsenic concentration 
in rice from different geographical areas have been suggested to be related to its sources and uptake efficiency of rice plant. In Asian arsenic endemic countries, inorganic arsenic-rich underground irrigation water is the main source of arsenic for rice plant. On the other hand, arsenical pesticides are the main source of arsenic for USA rice. In addition, microbial methylation of inorganic arsenic to organoarsenicals in the rice field (in water and rhizosphere soil) would also contribute to the organoarsenic content in raw rice.

\subsection{Variations in arsenic speciation in raw rice}

In addition to the geographical variations, arsenic speciation in raw rice also varied with the varieties, types, growing seasons and fractions of rice grain. These variations might be influenced by environmental factors as well as by internal factors such as morphological and physiological functions of the rice plants. But there are no clear evidences and specific information for which the speciation variations in rice grains of different rice verities occurred.

\subsubsection{Speciation variations in different varieties and types of rice}

Large variations in arsenic speciation in different Bangladeshi rice varieties have been reported by Williams et al. (2005). Organic and inorganic fractions of arsenic in chinigura, a local aromatic rice variety of Bangladesh, were about $49 \%$ and $48 \%$ of the total arsenic, respectively. However, inorganic species predominate in all other rice varieties with a range of $42-86 \%$ of the total arsenic. Miniket had the highest content of inorganic arsenic (86\% of the total arsenic) compared to other rice varieties. Arsenic speciation also varies with rice types of the same varieties. The DMAA(V) concentrations in USA white long rice grain were found to be between 0.05 and $0.26 \mu \mathrm{g} \mathrm{g}^{-1} \mathrm{~d}$. wt. (31-65\% of the total arsenic), while its concentrations in 
367 brown long rice were between 0.4 and $0.15 \mu \mathrm{g} \mathrm{g}^{-1} \mathrm{~d}$. wt. (32-45\% of the total arsenic) 368 (Heitkemper et al., 2001; Williams et al., 2005). In contrast, inorganic arsenic concentrations in 369 white basmati rice from India ranged between 0.02 and $0.04 \mu \mathrm{g} \mathrm{g}^{-1} \mathrm{~d}$. wt. (36-67\% of the total arsenic), while its concentrations in brown basmati and red long rice were about 0.04 and 0.05

$\mu \mathrm{g} \mathrm{g}^{-1} \mathrm{~d}$. wt. representing 61 and 65\% of the total arsenic, respectively (Williams et al., 2005). Inorganic arsenic concentrations in white rice from Taiwan and Jasmine rice from Thailand were about $0.11-0.51$ and $0.11 \mu \mathrm{g} \mathrm{g}^{-1} \mathrm{~d}$. wt. comprising $58-67 \%$ and $74 \%$ of the total arsenic content, respectively (Williams et al., 2005).

\subsubsection{Speciation variations in rice of different growing seasons}

Arsenic speciation in rice of different growing season has been reported from Bangladesh by Williams et al. (2006). They studied arsenic speciation in Bangladeshi rice grown in amon and boro seasons. Results showed that there were no statistical differences between amon and boro rice in terms of percentage inorganic arsenic content, although the relative amount of inorganic arsenic in boro rice (around $81-83 \%$ of the total arsenic) was higher than that in amon rice (around $60-71 \%$ of the total arsenic). These variations were possibly more related to the rice cultivars (varieties) than the growing seasons as significant differences in inorganic arsenic concentrations in different Bangladeshi rice varieties have been reported by other researchers (Williams et al., 2005).

\subsubsection{Speciation variations in different fractions of raw rice}

Arsenic speciation also varies with fractions of rice grain. Sun et al. (2008) analyzed the concentrations of arsenic species in different fractions of two Chinese and four Bangladeshi rice 
varieties. They found that the concentrations of the organoarsenic species (DMAA + MMAA) were fairly uniform throughout the grain $\left(0.18 \pm 0.05,0.20 \pm 0.06\right.$, and $0.18 \pm 0.03 \mu \mathrm{g} \mathrm{g}^{-1} \mathrm{~d}$. wt. for polished grain, whole grain, and bran, respectively). The mean concentrations of inorganic arsenic species in different fractions of rice grain also varied greatly $(0.21 \pm 0.03,0.40 \pm 0.08$, and $1.9 \pm 0.3 \mu \mathrm{g} \mathrm{g}^{-1} \mathrm{~d}$. wt. for polished grain, whole grain, and bran, respectively). Percentage inorganic arsenic content ranged from 24 to $60 \%$, 38 to $64 \%$, and 51 to $67 \%$ in polished grain, whole grain, and bran, respectively. The results reveal greater variations in inorganic arsenic concentrations compared to that of organoarsenic species, and the trend of percentage inorganic arsenic content was polished grain < whole grain < bran. Meharg et al. (2008b) reported higher percentage of inorganic arsenic in brown rice (whole grain) compared to that in polished rice (white grain). Meharg et al. (2008b) also found that percentage inorganic arsenic decreased with the increase of total grain arsenic. Market-basket study in USA by Zavala et al. (2008) also reported that the DMAA concentration in rice increased with the increase of total arsenic concentration. But they did not consider the changes in grain arsenic speciation whether the rice was polished or not. It is not clear why the concentration of organoarsenic species increased with the increase of total arsenic concentration in rice grain. Whatever the reasons were, percentage increase of organoarsenic species in rice grain is considered to be better for humans since these species are less toxic.

\section{Arsenic concentrations and speciation in cooked rice}

The residents of arsenic contaminated areas of Bangladesh and West Bengal (India) depend mostly on rice for their daily caloric intake, and high arsenic concentration in rice indicates that rice is the major dietary source of arsenic for the population of this area (Mondal 
and Polya, 2008; Rahman et al., 2011). In South Asian countries, rice is usually cooked with a substantial amount of water. A number of studies reveal the influence of cooking methods on the retention of total and organic arsenic in cooked rice (Bae et al., 2002; Pal et al., 2009; Raab et al., 2009; Rahman et al., 2006; Sengupta et al., 2006; Signes et al., 2008b), which is summarized in Table 2. In arsenic-contaminated areas of Bangladesh, approximately 10-35\% higher arsenic was found in cooked rice compared to that in raw rice (Misbahuddin, 2003). The additional arsenic is supposed to come from arsenic-contaminated cooking water. The increase of total arsenic concentration in cooked rice was resulted either from chelation by rice grains or due to evaporation during the cooking process (Rahman et al., 2011).

The effect of arsenic concentration in cooking water on the retention of arsenic in cooked rice is of great relevance to the South Asian countries where arsenic concentration in groundwater used for cooking has been reported to be much higher than the maximum allowable limit by World Health Organization (WHO) $\left(10 \mu \mathrm{g}^{-1}\right)$. The total arsenic concentration in cooked rice is claimed to be less than that in raw rice if the cooking water contain low level of arsenic (Bae et al., 2002). Pal et al. (2009) also reported that the concentration of total arsenic in rice cooked with water containing low level of arsenic $\left(<0.003 \mu \mathrm{g} \mathrm{l}^{-1}\right)$ was lower $\left(0.07-0.02 \mu \mathrm{g} \mathrm{g}^{-1} \mathrm{~d}\right.$. wt.) than that in raw rice $\left(0.25-0.08 \mu g^{-1} \mathrm{~d}\right.$. wt.) (Table 2). Not only the concentrations of arsenic in cooking water but also the cooking methods (the ways the rice is cooked for consumption) have significant influence on arsenic retention in cooked rice (Rahman et al., 2006; Sengupta et al., 2006). Most of the populations of South Asian countries consume parboiled rice (boiling and drying raw rice before dehusking/milling). But the populations of $\mathrm{E}$ and SE Asian countries and Japan solely use non-parboiled rice for cooking. Moreover, the rice cooking method also differs even within the locality of a county. In some countries, people cook 
rice with excess water and discard the gruel (concentrated cooking water) after cooking. This cooking procedure is popular in South Asian countries. On the other hand, cooking rice with limited water (therefore, no gruel remain after cooking) is a popular method worldwide. It has been reported that these different rice cooking methods affect the retention and the subsequent intake of arsenic from rice (Rahman et al., 2006; Sengupta et al., 2006; Signes et al., 2008b).

Arsenic concentration in non-parboiled rice cooked with limited water was $0.75 \pm 0.04$ $1.09 \pm 0.06 \mu \mathrm{g} \mathrm{g}^{-1}$ d. wt. $(n=3)$, which was about $13-37 \%$ higher than that in raw rice, and 27$60 \%$ higher than that in rice cooked with excess water (Rahman et al., 2006). In the same study, Rahman et al. (2006) also found that total arsenic concentration in parboiled rice cooked with limited water was about $45 \%$ higher than that in rice cooked with excess water. On the other hand, arsenic concentration in parboiled rice cooked with excess water was about $6.59 \%$ less than that in raw rice, while its concentration in gruel was about $57.18 \%$ higher than that in raw rice. These results elucidate that arsenic concentration in cooked rice is influenced by cooking method, arsenic concentration in raw rice and cooking water. Cooking rice with excess water results in the decrease of arsenic concentration in cooked rice when gruel is discarded, while its concentration increased significantly when rice is cooked with limited water and the gruel is not discarded. Raab et al. (2009) also found that cooking rice with high volume (excess) water (water : rice $=6: 1$ ) reduced total and inorganic arsenic burden in cooked rice by $35 \%$ and $45 \%$, while cooking with low volume (limited) water did not remove arsenic substantially. Sengupta et al. (2006) reported that cooking rice with low-arsenic water by the traditional cooking method in India (wash until clear, rice : water $=1: 6$, and discard excess water (gruel) after cooking) removed up to $57 \%$ of the arsenic burden from cooked rice. This removal of arsenic was irrespective to the concentration of arsenic in raw rice and cooking water, which might be 
because the water soluble arsenic was released from soft cooked rice into the cooking water (gruel) during cooking process, and was discarded with gruel after cooking. But arsenic concentration in cooked rice was found to be increased by $35-40 \%$ when arsenic concentration in cooking water was $50 \mu \mathrm{g} \mathrm{l}^{-1}$ (standard for many developing countries) (Sengupta et al., 2006). Rahman et al. (2006) also found the increase of arsenic concentration in cooked rice when the cooking water was arsenic contaminated. This was because arsenic is absorbed by rice (through osmotic process) from cooking water during the cooking process.

Arsenic speciation in cooked rice depends on its speciation in raw rice and in cooking water since arsenic speciation changes have not been found to occur during cooking process. Laparra et al. (2005) investigated the effect of inorganic arsenic in cooking water on total and inorganic arsenic retention in cooked rice of different types collected from Spanish super markets. They observed that there were no important modifications in the total and inorganic arsenic concentrations in cooked rice when cooked with uncontaminated water. In contrast, addition of $\mathrm{As}(\mathrm{V})$ in cooking water produced significant increase in inorganic arsenic content in cooked rice (Table 2). The increase of total and inorganic arsenic concentrations in cooked rice was depended on $\mathrm{As}(\mathrm{V})$ concentration in cooking water as well as on rice types. For example, arsenic concentrations in raw basmati and round white rice were $0.05 \pm 0.001$ and $0.13 \pm 0.008 \mu \mathrm{g}$ $\mathrm{g}^{-1} \mathrm{~d}$. wt., respectively. When these rice were cooked with water containing $0.6 \mu \mathrm{l}^{-1}$ of $\mathrm{As}(\mathrm{V})$, total arsenic concentrations in cooked basmati and round white rice were found to be $2.36 \pm 0.080$ and $2.29 \pm 0.050 \mu \mathrm{g} \mathrm{g}^{-1} \mathrm{~d}$. wt. of which inorganic arsenic were 96 and $81 \%$ of the total arsenic, respectively. In addition, total and inorganic arsenic concentrations were low (1.96 \pm 0.01 and $1.66 \pm 0.002 \mu \mathrm{g} \mathrm{g}^{-1} \mathrm{~d}$. wt., respectively) when the rice was cooked with water containing $0.4 \mu \mathrm{g} \mathrm{l}^{-1}$ $\mathrm{As}(\mathrm{V})\left(\right.$ ), and there concentrations were increased $\left(4.21 \pm 0.09\right.$ and $3.73 \pm 0.04 \mu \mathrm{g} \mathrm{g}^{-1} \mathrm{~d}$. wt., 
respectively) when the rice was cooked with water containing $1.0 \mu \mathrm{g}^{-1} \mathrm{As}(\mathrm{V})()$. These results imply that, in addition to the concentration and speciation in raw rice, arsenic concentration and speciation in cooked rice are also varied for rice type as well as for the speciation and concentration of arsenic in cooking water.

\subsection{Contribution of rice to dietary intake of arsenic}

\subsection{Dietary intake of arsenic from rice}

It has been proved that arsenic pollution poses a serious threat to human health. To minimize the health risks of arsenic toxicity, the main concern is to identify the sources of exposure to avoid the intake of this toxic element. Although there are many possible routes of arsenic exposure ((Rahman et al., 2008a), the majors are inhalation (Pal et al., 2007), ingestion, and dermal contact (Mondal and Polya, 2008), of which ingestion is the largest contributor. Among the many possible pathways of arsenic ingestion (Mondal and Polya, 2008), epidemiological data, that has been published during last couple of years, revealed that contaminated drinking groundwater is the major source of dietary arsenic in many countries, especially in S and SE Asia. A number of recent studies showed that, in addition to the contaminated drinking water, foods such as rice, vegetables and fishes would also be potential sources of dietary arsenic exposure (Bhattacharya et al., 2010; Lin et al., 2004; Ohno et al., 2007; Roychowdhury et al., 2003; Schoof et al., 1999; Signes-Pastor et al., 2009; Signes-Pastor et al., 2008). High levels of arsenic (0.03-1.83 $\mu \mathrm{g} \mathrm{g}^{-1} \mathrm{~d}$. wt.) have been found in rice grain from some $\mathrm{S}$ and SE Asian countries (discussed in the previous sections), which was the contribution of extensive use of arsenic-contaminated groundwater for rice cultivation (Carey et al., 2010; Khan et al., 2009; Khan et al., 2010b; Rahman et al., 2008a; Rahman et al., 2009; Singh et al., 2010). 
Therefore, rice is supposed to be another major source of arsenic exposure followed by drinking groundwater (Mondal and Polya, 2008; Stone, 2008). Williams et al. (2006) modeled the possible intake of inorganic arsenic from rice with the equivalent intake from drinking water for a typical Bangladeshi diet. It was predicted that the daily consumption of rice with a total arsenic level of $0.08 \mu \mathrm{g} \mathrm{g}^{-1} \mathrm{~d}$. wt. would be equivalent to a drinking water arsenic level of $10 \mu \mathrm{g} \mathrm{l^{-1 }}$.

Arsenic in rice is a threat to human health not only for its high concentration but also for its speciation. Although previous studies have revealed drinking water as the largest source of inorganic arsenic for humans, rice is also considered to be another significant source of this arsenic species. A number of arsenic speciation studies showed that about 42 to $91 \%$ of the total arsenic in S and SE Asian rice is toxic inorganic species (Heitkemper et al., 2001; Meharg et al., 2008b; Meharg et al., 2009; Schoof et al., 1998; Schoof et al., 1999; Williams et al., 2005; Zhu et al., 2008b), while the major species in USA rice is organic DMAA (Williams et al., 2005). A more recent study showed that rice products such as breakfast cereals, rice crackers, rice milk, baby rice and other rice condiments also contain high percentage of inorganic arsenic (75-90\%) (Meharg et al., 2008a; Meharg et al., 2008c; Sun et al., 2009). Some other studies also revealed that the total (Bae et al., 2002; Laparra et al., 2005; Pal et al., 2009; Rahman et al., 2006; Rahman et al., 2011; Sengupta et al., 2006) and inorganic arsenic (Laparra et al., 2005; Smith et al., 2006) concentrations in cooked rice increased due to cooking with arsenic-rich water (Laparra et al., 2005; Raab et al., 2009). Cooking rice with water containing $0.05 \mathrm{mg} \mathrm{l}^{-1}$ of As(V) produced 5-17-fold higher inorganic arsenic content in cooked rice than that in raw rice (Laparra et al., 2005).

Second to fish and seaweed, rice is the major dietary source of total arsenic (around 34\%) for the people of North America and EU (Meharg and Rahman, 2003; Schoof et al., 1999). The 
contribution of rice to the dietary intake of arsenic in Bangladesh, where rice is the subsistence food, was modeled by Meharg and Rahman (2003). They showed that with drinking water intake of $0.1 \mathrm{mg} \mathrm{l}^{-1}$, dietary intake of arsenic from rice containing 0.1 and $0.2 \mu \mathrm{g} \mathrm{g}^{-1} \mathrm{~d}$. wt. of total arsenic would be around 17.3 and $29.6 \%$, respectively. If the grain arsenic concentration was 2

$\mu \mathrm{g} \mathrm{g}^{-1} \mathrm{~d}$. wt. (the level found in rice from some areas of the country), the contributions would be 98, 80, and 30\% at drinking water arsenic concentrations of $0.01,0.1$ and $1 \mathrm{mg} \mathrm{l}^{-1}$, respectively. Rahman et al. (2008a) reported that with average rice consumption of 400 to $650 \mathrm{~g} \mathrm{~d}^{-1}$ (the typical range of rice consumption by adults in Bangladesh (Duxbury et al., 2003)), arsenic intake would be 0.16 to $0.27 \mathrm{mg} \mathrm{d}^{-1}$ if the concentration of arsenic in rice was $0.4 \mu \mathrm{g} \mathrm{g}^{-1} \mathrm{~d}$. wt. In contrast, dietary intake of arsenic from drinking water would be 0.2 to $0.3 \mathrm{mg} \mathrm{d}^{-1}$ for adult consuming 4 to $6 \mathrm{~L}$ water (the typical range of water consumption by adult of the country. The rate would be much higher for the rural people since they involved mostly in agrarian manual labor (Farmer and Johnson, 1990)) containing $0.05 \mathrm{mg} \mathrm{l}^{-1}$ arsenic, respectively. Thus, it is evident that rice would be a major source for dietary arsenic intake for the population of $\mathrm{S}$ and SE Asian countries where rice is the subsistence diet.

\subsection{Bioavailability of arsenic from rice}

The toxic inorganic arsenic species is readily assimilated into blood stream (Meharg and Rahman, 2003). Therefore, bioavailability and bioaccumulation of arsenic species from cooked rice are important for its intake in humans from this food source. Laparra et al. (2005) investigated the bioaccessibility and bioavailability of inorganic arsenic in cooked rice to assess the potential toxicological risk of this species. Results showed that the total arsenic concentrations in bioaccessible fractions were 1.06-3.39 $\mu \mathrm{g} \mathrm{g}^{-1} \mathrm{~d}$. wt. when its concentrations in 


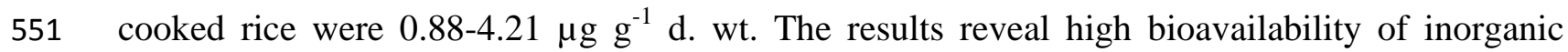
552 arsenic from cooked rice ( $>90 \%)$. In addition, the concentrations of inorganic arsenic in 553 bioaccessible fractions of cooked rice varied from 0.8 to $3.1 \mu \mathrm{g} \mathrm{g}^{-1} \mathrm{~d}$. wt. This indicates that a

554 significant fraction of the inorganic arsenic can be available for intestinal absorption. To further estimate the bioavailability (retention, transport, and uptake) inorganic arsenic, however, the bioaccessible fractions were added to Caco-2 cells. Results showed that arsenic retention, transport, and uptake by the cells from cooked rice were 0.6-6.4, 3.3-11.4, and 3.9-17.8\%, respectively. Considering the lowest (3.9\%) and the highest (17.8\%) total arsenic uptake values of the study, Laparra et al. (2005) estimated that the daily consumption of 5.7 and $1.2 \mathrm{~kg}$ cooked rice containing $4.21 \pm 0.09$ and $2.29 \pm 0.05 \mu \mathrm{g} \mathrm{g}^{-1} \mathrm{~d}$. wt., respectively, would be required to reach the tolerable daily intake (TDI) of inorganic arsenic recommended by the WHO $\left(2.1 \mu \mathrm{g} \mathrm{d}^{-1} \mathrm{~kg}\right.$

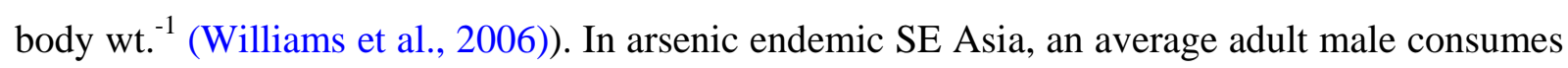
$1.5 \mathrm{~kg}$ cooked rice a day indicating that the people of this region might reach the TDI of arsenic only from rice diet.

Williams et al. (2006) also determined the total and inorganic arsenic concentrations in Bangladeshi rice to estimate the contribution of inorganic arsenic to the maximum tolerable daily intake (MTDI) for a Bangladeshi adult of $60 \mathrm{~kg}$ weight (Table 3). Results showed that the contribution of inorganic arsenic in rice to MTDI of arsenic for a Bangladeshi adult would be 5579\% depending on inorganic arsenic concentration and rice type. When the concentrations of inorganic arsenic in rice were high, the MTDI exceeded the 100\% level (Ohno et al., 2007; Schoof et al., 1998; Sun et al., 2008). The contribution of inorganic arsenic to the MTDI for a 60 kg person is about 4-36\% since the concentrations of this arsenic species in American, European and Canadian rice are low (Table 3). 


\section{Conclusion}

Rice comprises the major part of daily diet of the population of S and SE Asian countries.

577

578

579

580

581

582

Irrigation of arsenic-contaminated groundwater for rice cultivation has resulted high deposition of this toxic element in the top soil posing a serious threat to the sustainable rice farming in this region. Compared to other cereal crops, rice contains higher amount of arsenic most of which is toxic inorganic species. A number of studies reveal that, in addition to the drinking water, rice is another major and potential source of dietary arsenic intake. Inorganic arsenic is classified as a human carcinogen by the international agency for research on cancer because of its high toxicity (Laparra et al., 2005). Exposure to inorganic arsenic may cause various internal cancers- liver, bladder, kidney, and lungs as well as other health problems, including skin cancer and diabetes (Booth, 2009). High concentration of inorganic arsenic in S and SE Asian rice is, therefore, a health emergency for the population of this region.

In a recent study, Meharg et al. (2009) modeled cancer risks of arsenic from rice in Bangladesh, China, India, Italy, and USA by multiplying projected daily intake of inorganic arsenic in rice and a risk factor proposed by the United States Environmental Protection Agency

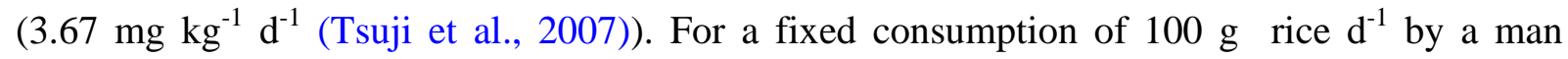
weighting $60 \mathrm{~kg}$, the median excess internal cancer rate was highest in Bangladesh (22 per 10,000 people) followed by China (15 per 10,000), India (7 per 10,000), and Italy and USA ( 1 per 10,000). It was speculated from this estimation that the median cancer risk from arsenic-rich rice was about 200, 150, and 70 times higher than the WHO standard (1 per 100,000 people) for Bangladesh, China, and India, respectively. Using a probabilistic risk assessment, Mondal and Polya (2008) projected that the contributions of drinking water and cooked rice to median total 
risk for the population of Chakdaha block, Nadia district, India would 48 and 8\%, respectively. Thus, arsenic-rich rice would be a potential health risk for the population of arsenic-affected $\mathrm{S}$ and SE Asia, particularly in Bangladesh and West Bengal.

Another important concern relevant human health is the increase of total and inorganic arsenic concentrations in cooked rice. The increased arsenic in cooked rice comes mainly from arsenic-contaminated cooking water. Therefore, it is important to investigate and justify the bioavailability and bioaccumulation of arsenic species from rice. Unfortunately, information on this issue is very limited. Researchers should focus their efforts in this issue to estimate the real health hazard of arsenic from rice diet.

\section{Acknowledgement}

The authors wish to thank the Japan Society for the Promotion of Science (JSPS) for financial support by Grants-in-Aid for Scientific Research (20.08343) in preparing this review paper. The reviewers are also acknowledged for their contribution in improving the quality and merit of the paper.

\section{References}

Alam MB, Sattar MA. Assessment of arsenic contamination in soils and waters in some areas of Bangladesh. Water Sci Technol 2000: 185-92.

Alvarez-Fernandez A, Garcia-Marco S, Lucena JJ. Evaluation of synthetic iron (III)-chelates $\left(\mathrm{EDDHA} / \mathrm{Fe}^{3+}, \mathrm{EDDHMA} / \mathrm{Fe}^{3+}\right.$ and the novel EDDHSA/ $\mathrm{Fe}^{3+}$ ) to correct iron chlorosis. Eur $\mathrm{J}$ Agron 2005; 22: 119-30.

Bae M, Watanabe C, Inaoka T, Sekiyama M, Sudo N, Bokul MH, et al. Arsenic in cooked rice in Bangladesh. Lancet 2002; 360: 1839-40.

Bar-Ness E, Hadar Y, Chen Y, Romheld V, Marschner H. Short-term effects of rhizosphere microorganisms on Fe uptake from microbial siderophores by maize and oat. Plant Physiol 1992; 100: 451-56. 
Bhattacharya P, Samal AC, Majumdar J, Santra SC. Arsenic contamination in rice, wheat, pulses, and vegetables: A study in an arsenic affected area of West Bengal, India. Water Air and Soil Pollution 2010; 213: 3-13.

Booth B. Arsenic in U.S. rice varies by region. Environ Sci Technol 2007; 41: 2075-76.

Booth B. Arsenic speciation varies with type of rice. Environ Sci Technol 2008; 42: 3484-85.

Booth B. Cancer rates attributable to arsenic in rice vary globally. Environ Sci Technol 2009; 43: 1243-44.

Brammer H, Ravenscroft P. Arsenic in groundwater: A threat to sustainable agriculture in South and South-east Asia. Environ Int 2009; 35: 647-54.

Carey AM, Scheckel KG, Lombi E, Newville M, Choi Y, Norton GJ, et al. Grain unloading of arsenic species in rice. Plant Physiol 2010; 152: 309-19.

Chatterjee D, Haider D, Majumder S, Biswas A, Nath B, Bhattacharya P, et al. Assessment of arsenic exposure from groundwater and rice in Bengal Delta Region, West Bengal, India. Water Res 2010; 44: 5803-12.

Crowley D, Römheld V, Marschner H, Szaniszlo P. Root-microbial effects on plant iron uptake from siderophores and phytosiderophores. Plant Soil 1992; 142: 1-7.

Crowley DE, Wang YC, Reid CPP, Szaniszlo PJ. Mechanisms of iron acquisition from siderophores by microorganisms and plants. Plant Soil 1991; 130: 179-98.

Dahal BM, Fuerhacker M, Mentler A, Karki KB, Shrestha RR, Blum WEH. Arsenic contamination of soils and agricultural plants through irrigation water in Nepal. Environ Pollut 2008; 155: 157-63.

Das HK, Mitra AK, Sengupta PK, Hossain A, Islam F, Rabbani GH. Arsenic concentrations in rice, vegetables, a fish in Bangladesh: A preliminary study. Environ Int 2004; 30: 383-87.

Dittmar J, Voegelin A, Maurer F, Roberts LC, Hug SJ, Saha GC, et al. Arsenic in soil and irrigation water affects arsenic uptake by rice: Complementary insights from field and pot studies. Environ Sci Technol 2010; 44: 8842-48.

Dittmar J, Voegelin A, Roberts LC, Hug SJ, Saha GC, Ali MA, et al. Spatial distribution and temporal variability of arsenic in irrigated rice fields in Bangladesh. 2. Paddy soil. Environ Sci Technol 2007; 41: 5967-72.

Duxbury JM, Mayer AB, Lauren JG, Hassan N. Food chain aspects of arsenic contamination in Bangladesh: Effects on quality and productivity of rice. J Environ Sci Health A Toxic/Hazar Subs Environ Eng 2003; 38: 61-69.

Farmer J, Johnson L. Assessment of occupational exposure to inorganic arsenic based on urinary concentrations and speciation of arsenic. Br J Ind Med 1990; 47: 342.

Gurung JK, Ishiga H, Khadka MS. Geological and geochemical examination of arsenic contamination in groundwater in the Holocene Terai Basin, Nepal. Environ Geol 2005; 49: 98-113.

Hasegawa H, Rahman MA, Saitoh K, Ueda K. Effect of biodegradable chelating ligand on iron bioavailability and radish growth. J Plant Nutr 2010; 33: 933-42. 
Hasegawa H, Rahman MA, Saitou K, Kobayashi M, Okumura C. Influence of chelating ligands on bioavailability and mobility of iron in plant growth media and their effect on radish growth. Environ Exp Bot 2011; 71: 345-51.

Heitkemper DT, Vela NP, Stewart KR, Westphal CS. Determination of total and speciated arsenic in rice by ion chromatography and inductively coupled plasma mass spectrometry. J Anal At Spectrom 2001; 16: 299-306.

Hu Y, Li JH, Zhu YG, Huang YZ, Hu HQ, Christie P. Sequestration of As by iron plaque on the roots of three rice (Oryza sativa L.) cultivars in a low-P soil with or without $\mathrm{P}$ fertilizer. Environ Geochem Health 2005; 27: 169-76.

Hu ZY, Zhu YG, Li M, Zhang LG, Cao ZH, Smith EA. Sulfur (S)-induced enhancement of iron plaque formation in the rhizosphere reduces arsenic accumulation in rice (Oryza sativa L.) seedlings. Environ Pollut 2007; 147: 387-93.

Ishimaru Y, Suzuki M, Tsukamoto T, Suzuki K, Nakazono M, Kobayashi T, et al. Rice plants take up iron as an $\mathrm{Fe}^{3+}$-phytosiderophore and as $\mathrm{Fe}^{2+}$. Plant J 2006; 45: 335-46.

Islam M, Jahiruddin M, Islam S. Assessment of arsenic in the water-soil-plant systems in Gangetic floodplains of Bangladesh. Asian J Plant Sci 2004; 3: 489-93.

Khan MA, Islam MR, Panaullah GM, Duxbury JM, Jahiruddin M, Loeppert RH. Fate of irrigation-water arsenic in rice soils of Bangladesh. Plant Soil 2009; 322: 263-77.

Khan MA, Islam MR, Panaullah GM, Duxbury JM, Jahiruddin M, Loeppert RH. Accumulation of arsenic in soil and rice under wetland condition in Bangladesh. Plant Soil 2010a; 333: 263-74.

Khan MA, Stroud JL, Zhu YG, McGrath SP, Zhao FJ. Arsenic bioavailability to rice is elevated in Bangladeshi paddy soils. Environ Sci Technol 2010b; 44: 8515-21.

Kohnhorst A. Arsenic in groundwater in selected countries in south and southeast Asia: A review. J Trop Med Paracitol 2005; 28: 73-82.

Kraemer S. Iron oxide dissolution and solubility in the presence of siderophores. Aquat Sci Res Acr Bound 2004; 66: 3-18.

Laparra JM, Velez D, Barbera R, Farre R, Montoro R. Bioavailability of inorganic arsenic in cooked rice: Practical aspects for human health risk assessments. J Agric Food Chem 2005; 53: 8829-33.

Lin HT, Wong SS, Li GC. Heavy metal content of rice and Shellfish in Taiwan. J Food Drug Anal 2004; 12: $167-74$.

Liu H, Probst A, Liao B. Metal contamination of soils and crops affected by the Chenzhou lead/zinc mine spill (Hunan, China). Sci Total Environ 2005; 339: 153-66.

Liu WJ, Zhu YG, Hu Y, Williams PN, Gault AG, Meharg AA, et al. Arsenic sequestration in iron plaque, its accumulation and speciation in mature rice plants (Oryza sativa L.). Environ Sci Technol 2006; 40: 5730-36.

Mandal BK, Suzuki KT. Arsenic round the world: A review. Talanta 2002; 58: 201-35. 
Mass MJ, Tennant A, Roop BC, Cullen WR, Styblo M, Thomas DJ, et al. Methylated trivalent arsenic species are genotoxic. Chem Res Toxicol 2001; 14: 355-61.

Meharg AA. Arsenic in rice - understanding a new disaster for South-East Asia. Trends Plant Sci 2004; 9: 415-17.

Meharg AA, Deacon C, Campbell RCJ, Carey AM, Williams PN, Feldmann J, et al. Inorganic arsenic levels in rice milk exceed EU and US drinking water standards. J Environ Monit 2008a; 10: 42831.

Meharg AA, Hartley Whitaker J. Arsenic uptake and metabolism in arsenic resistant and nonresistant plant species. New Phytol 2002; 154: 29-43.

Meharg AA, Lombi E, Williams PN, Scheckel KG, Feldmann J, Raab A, et al. Speciation and localization of arsenic in white and brown rice grains. Environ Sci Technol 2008b; 42: 1051-57.

Meharg AA, Rahman M. Arsenic contamination of Bangladesh paddy field soils: Implications for rice contribution to arsenic consumption. Environmental Science \& Technology 2003; 37: 229-34.

Meharg AA, Sun G, Williams PN, Adomako E, Deacon C, Zhu YG, et al. Inorganic arsenic levels in baby rice are of concern. Environ Pollut 2008c; 152: 746-9.

Meharg AA, Williams PN, Adomako E, Lawgali YY, Deacon C, Villada A, et al. Geographical variation in total and inorganic arsenic content of polished (white) rice. Environ Sci Technol 2009; 43 : 1612-17.

Misbahuddin M. Consumption of arsenic through cooked rice. Lancet 2003; 361: 435-36.

Mondal D, Banerjee M, Kundu M, Banerjee N, Bhattacharya U, Giri AK, et al. Comparison of drinking water, raw rice and cooking of rice as arsenic exposure routes in three contrasting areas of West Bengal, India. Environ Geochem Health 2010; 32: 463-77.

Mondal D, Polya DA. Rice is a major exposure route for arsenic in Chakdaha block, Nadia district, West Bengal, India: A probabilistic risk assessment. Appl Geochem 2008; 23: 2987-98.

Mukherjee A, Sengupta MK, Hossain MA, Ahamed S, Das B, Nayak B, et al. Arsenic contamination in groundwater: a global perspective with emphasis on the Asian scenario. J Health Popul Nutr 2006; 24: 142-63.

Musaiger AO, D'Souza R. The effects of different methods of cooking on proximate, mineral and heavy metal composition of fish and shrimps consumed in the Arabian Gulf. Arch Latinoam Nutr 2008; 58: $103-09$.

Ng JC. Environmental contamination of arsenic and its toxicological impact on humans. Environ Chem 2005; 2: 146-60.

Ninno Cd, Dorosh PA. Averting a food crisis: Private imports and public targeted distribution in Bangladesh after the 1998 flood. Agric Econ 2001; 25: 337-46.

Nordstrom DK. Worldwide occurrences of arsenic in ground water. Science 2002; 296: 2143-45. 
Ohno K, Matsuo Y, Kimura T, Yanase T, Rahman MH, Magara Y, et al. Effect of rice-cooking water to the daily arsenic intake in Bangladesh: Results of field surveys and rice-cooking experiments. Water Sci Technol 2009; 59: 195-201.

Ohno K, Yanase T, Matsuo Y, Kimura T, Hamidur Rahman M, Magara Y, et al. Arsenic intake via water and food by a population living in an arsenic-affected area of Bangladesh. Sci Total Environ 2007; 381: 68-76.

Pal A, Chowdhury UK, Mondal D, Das B, Nayak B, Ghosh A, et al. Arsenic burden from cooked rice in the populations of arsenic affected and nonaffected areas and Kolkata city in West-Bengal, India. Environ Sci Technol 2009; 43: 3349-55.

Pal A, Nayak B, Das B, Hossain MA, Ahameda S, Chakraborti D. Additional danger of arsenic exposure through inhalation from burning of cow dung cakes laced with arsenic as a fuel in arsenic affected villages in Ganga-Meghna-Brahmaputra plain. J Environ Monit 2007; 9: 1067-70.

Petrick JS, Ayala-Fierro F, Cullen WR, Carter DE, Aposhian VH. Monomethylarsonous acid (MMA ${ }^{\mathrm{III}}$ ) is more toxic than arsenite in Chang human hepatocytes. Toxicol Appl Pharmacol 2000; 163: 20307.

Phuong TD, Chuong PV, Khiem DT, Kokot S. Elemental content of Vietnamese rice. Part 1. Sampling, analysis and comparison with previous studies. Analyst 1999; 124: 553-60.

Pillai TR, Yan WG, Agrama HA, James WD, Ibrahim AMH, McClung AM, et al. Total grain-arsenic and arsenic-species concentrations in diverse rice cultivars under flooded conditions. Crop Sci 2010; 50: 2065-75.

Postma D, Larsen F, Minh Hue NT, Duc MT, Viet PH, Nhan PQ, et al. Arsenic in groundwater of the Red River floodplain, Vietnam: Controlling geochemical processes and reactive transport modeling. Geochim Cosmochim Acta 2007; 71: 5054-71.

Potera C. US rice serves up arsenic. Environ Health Persp 2007; 115: A296-A96.

Raab A, Baskaran C, Feldmann J, Meharg AA. Cooking rice in a high water to rice ratio reduces inorganic arsenic content. J Environ Monit 2009; 11: 41-44.

Rahman MA, Hasegawa H, Rahman MA, Rahman MM, Miah MAM. Influence of cooking method on arsenic retention in cooked rice related to dietary exposure. Sci Total Environ 2006; 370: 51-60.

Rahman MA, Hasegawa H, Rahman MM, Miah MA. Accumulation of arsenic in tissues of rice plant (Oryza sativa L.) and its distribution in fractions of rice grain. Chemosphere 2007a; 69: 942-8.

Rahman MA, Hasegawa H, Rahman MM, Miah MAM, Tasmin A. Arsenic accumulation in rice (Oryza sativa L.): Human exposure through food chain. Ecotoxicol Environ Saf 2008a; 69: 317-24.

Rahman MA, Hasegawa H, Rahman MM, Rahman MA, Miah MAM. Accumulation of arsenic in tissues of rice plant (Oryza sativa L.) and its distribution in fractions of rice grain. Chemosphere 2007b; 69: $942-48$. 
Rahman MA, Hasegawa H, Ueda K, Maki T, Rahman MM. Influence of chelating ligands on arsenic uptake by hydroponically grown rice seedlings (Oryza sativa L.): A preliminary study. CLEAN Soil Air Water 2008b; 36: 521-27.

Rahman MA, Ismail MMR, Hasegawa H. Cooking: Effects on dietary exposure to arsenic from rice and vegetables. In: Nriagu JO, editor. Encyclopedia of Environmental Health. 1. Elsevier, Burlington, 2011, pp. 828-33.

Rahman MM, Owens G, Naidu R. Arsenic levels in rice grain and assessment of daily dietary intake of arsenic from rice in arsenic-contaminated regions of Bangladesh-implications to groundwater irrigation. Environ Geochem Health 2009; 31: 179-87.

Ren XL, Liu QL, Wu DX, Shu QY. Variations in concentration and distribution of health-related elements affected by environmental and genotypic differences in rice grains. Rice Sci 2007; 13 : 170-78.

Roberts LC, Hug SJ, Dittmar J, Voegelin A, Saha GC, Ali MA, et al. Spatial distribution and temporal variability of arsenic in irrigated rice fields in Bangladesh. 1. Irrigation water. Environ Sci Technol 2007; 41: 5960-66.

Romheld V. Different strategies for iron acquisition in higher plants. Physiol Plant 1987; 70: 231-34.

Romheld V, Marschner H. Evidence for a specific uptake system for iron phytosiderophores in roots of grasses. Plant Physiol 1986; 80: 175-80.

Roychowdhury T, Tokunaga H, Ando M. Survey of arsenic and other heavy metals in food composites and drinking water and estimation of dietary intake by the villagers from an arsenic-affected area of West Bengal, India. Sci Total Environ 2003; 308: 15-35.

Roychowdhury T, Uchino T, Tokunaga H, Ando M. Survey of arsenic in food composites from an arsenic-affected area of West Bengal, India. Food Chem Toxicol 2002; 40: 1611-21.

Schoof RA, Yost LJ, Crecelius E, Irgolic K, Goessler W, Guo HR, et al. Dietary arsenic intake in Taiwanese districts with elevated arsenic in drinking water. Hum Ecol Risk Ass 1998; 4: 117-35.

Schoof RA, Yost LJ, Eickhoff J, Crecelius EA, Cragin DW, Meacher DM, et al. A market basket survey of inorganic arsenic in food. Food Chem Toxicol 1999; 37: 839-46.

Sengupta MK, Hossain MA, Mukherjee A, Ahamed S, Das B, Nayak B, et al. Arsenic burden of cooked rice: Traditional and modern methods. Food Chem Toxicol 2006; 44: 1823-29.

Signes-Pastor AJ, Deacon C, Jenkins RO, Haris PI, Carbonell-Barrachina AA, Meharg AA. Arsenic speciation in Japanese rice drinks and condiments. J Environ Monit 2009; 11: 1930-34.

Signes-Pastor AJ, Mitra K, Sarkhel S, Hobbes M, Burlo F, de Groot WT, et al. Arsenic speciation in food and estimation of the dietary intake of inorganic arsenic in a rural village of West Bengal, India. $\mathrm{J}$ Agric Food Chem 2008; 56: 9469-74.

Signes A, Mitra K, Burlo F, Carbonell-Barrachina AA. Contribution of water and cooked rice to an estimation of the dietary intake of inorganic arsenic in a rural village of West Bengal, India. Food Addit Contam: Part A 2008a; 25: 41-50. 
Signes A, Mitra K, Burlo F, Carbonell-Barrachina AA. Effect of cooking method and rice type on arsenic concentration in cooked rice and the estimation of arsenic dietary intake in a rural village in West Bengal, India. Food Addit Contam: Part A 2008b; 25: 1345-52.

Singh V, Brar MS, Sharma P, Malhi SS. Arsenic in water, soil, and rice plants in the Indo-Gangetic plains of northwestern India. Commun Soil Sci Plant Anal 2010; 41: 1350-60.

Smedley PL. Arsenic occurrence in groundwater in South and East Asia. In: Kemper K, Minatullah K, editors. Towards a more Effective Operational Response. World Bank, Washington, DC, 2005, pp. 20-98.

Smith NM, Lee R, Heitkemper DT, Cafferky KD, Haque A, Henderson AK. Inorganic arsenic in cooked rice and vegetables from Bangladeshi households. Sci Total Environ 2006; 370: 294-301.

Stone R. Arsenic and paddy rice: A neglected cancer risk? Science 2008; 321: 184-5.

Sun G, Li X, Pi J, Sun Y, Li B, Jin Y, et al. Current research problems of chronic arsenicosis in China. J Health Popul Nutr 2006; 24: 176-81.

Sun GX, Williams PN, Carey AM, Zhu YG, Deacon C, Raab A, et al. Inorganic arsenic in rice bran and its products are an order of magnitude higher than in bulk grain. Environ Sci Technol 2008; 42: 7542-46.

Sun GX, Williams PN, Zhu YG, Deacon C, Carey AM, Raab A, et al. Survey of arsenic and its speciation in rice products such as breakfast cereals, rice crackers and Japanese rice condiments. Environ Int 2009; 35: 473-75.

Tamaki S, Frankenberger WTJ. Environmental chemistry of arsenic. Rev Environ Contam Toxicol 1992; 124: 79-110.

Torres-Escribano S, Leal M, Velez D, Montoro R. Total and inorganic arsenic concentrations in rice sold in Spain, effect of cooking, and risk assessments. Environ Sci Technol 2008; 42: 3867-72.

Tsuji JS, Yost LJ, Barraj LM, Scrafford CG, Mink PJ. Use of background inorganic arsenic exposures to provide perspective on risk assessment results. Regul Toxicol Pharmacol 2007; 48: 59-68.

Tuli R, Chakrabarty D, Trivedi PK, Tripathi RD. Recent advances in arsenic accumulation and metabolism in rice. Mol Breed 2010; 26: 307-23.

Williams PN, Islam MR, Adomako EE, Raab A, Hossain SA, Zhu YG, et al. Increase in rice grain arsenic for regions of Bangladesh irrigating paddies with elevated arsenic in groundwaters. Environmental Science \& Technology 2006; 40: 4903-08.

Williams PN, Price AH, Raab A, Hossain SA, Feldmann J, Meharg AA. Variation in arsenic speciation and concentration in paddy rice related to dietary exposure. Environ Sci Technol 2005; 39: 553140.

Williams PN, Raab A, Feldmann J, Meharg AA. Market basket survey shows elevated levels of As in South Central U.S. processed rice compared to California: Consequences for human dietary exposure. Environ Sci Technol 2007a; 41: 2178-83. 
Williams PN, Villada A, Deacon C, Raab A, Figuerola J, Green AJ, et al. Greatly enhanced arsenic shoot assimilation in rice leads to elevated grain levels compared to wheat and barley. Environ Sci Technol 2007b; 41: 6854-59.

Winkel L, Berg M, Amini M, Hug SJ, Annette Johnson C. Predicting groundwater arsenic contamination in Southeast Asia from surface parameters. Nature Geosci 2008; 1: 536-42.

Xie ZM, Huang CY. Control of arsenic toxicity in rice plants grown on an arsenic-polluted paddy soil. Commun Soil Sci Plant Anal 1998; 29: 2471-77.

Xu XY, McGrath SP, Meharg AA, Zhao FJ. Growing rice aerobically markedly decreases arsenic accumulation. Environ Sci Technol 2008; 42: 5574-79.

Zavala YJ, Duxbury JM. Arsenic in rice: I. Estimating normal levels of total arsenic in rice grain. Environ Sci Technol 2008; 42: 3856-60.

Zavala YJ, Gerads R, Gurleyuk H, Duxbury JM. Arsenic in Rice: II. Arsenic speciation in USA grain and implications for human health. Environ Sci Technol 2008; 42: 3861-66.

Zhu YG, Sun GX, Lei M, Teng M, Liu YX, Chen NC, et al. High percentage inorganic arsenic content of mining impacted and nonimpacted Chinese rice. Environ Sci Technol 2008a; 42: 5008-13.

Zhu YG, Williams PN, Meharg AA. Exposure to inorganic arsenic from rice: A global health issue? Environ Pollut 2008b; 154: 169-71. 
858 Table 1: The concentration ( $\mu \mathrm{g} \mathrm{g}^{-1} \mathrm{~d}$. wt.) of total, inorganic and organoarsenic fractions in raw rice from different countries

\begin{tabular}{|c|c|c|c|c|c|c|}
\hline Country & $\begin{array}{l}\text { Total As } \\
\text { mean (range) }\end{array}$ & $\begin{array}{l}\text { Inorganic As } \\
\text { mean (range) }\end{array}$ & $\begin{array}{l}\text { Organic As } \\
\text { mean (range) }\end{array}$ & $\begin{array}{l}\% \text { of inorganic } \\
\text { As mean (range) }\end{array}$ & Survey range & References \\
\hline Australia & $0.03(0.02-0.04)$ & - & - & - & - & (Williams et al., 2006) \\
\hline \multirow[t]{12}{*}{ Bangladesh } & $0.13(0.02-0.33)$ & $0.08(0.01-0.21)$ & - & 61 & market basket & (Meharg et al., 2009) \\
\hline & $0.50(0.03-1.84)$ & - & - & - & field & (Meharg and Rahman, 2003) \\
\hline & $0.34(0.15-0.59)$ & & & & field & (Ohno et al., 2007) \\
\hline & $0.39(0.26-0.58)$ & $0.39(0.26-0.58)$ & $0.005(0.001-0.010)$ & 100 & field & (Ohno et al., 2007) \\
\hline & $0.08-0.36(0.04-0.92)-$ aman & - & - & - & \multirow{2}{*}{ field } & \multirow{2}{*}{ (Williams et al., 2006) } \\
\hline & 0.14-0.51 (0.04-0.91)- boro & - & - & - & & \\
\hline & $0.23(0.18-0.31)-$ aman & $0.16(0.11-0.22)$ & - & $65(60-71)$ & \multirow{2}{*}{ market basket } & \multirow{2}{*}{ (Williams et al., 2006) } \\
\hline & 0.24 (0.21-0.27)- boro & $0.20(0.17-0.22)$ & - & $82(81-83)$ & & \\
\hline & $0.13(0.03-0.30)$ & $0.08(0.01-0.21)$ & $0.02\left(<\mathrm{LOD}^{*}-0.05\right)$ & $60(44-86)$ & market basket & (Williams et al., 2005) \\
\hline & $0.69(0.41-0.98)$ & $0.31(0.23-0.39)$ & $0.23(0.05-0.43)$ & $44(45-59)$ & - & (Sun et al., 2008) \\
\hline & $0.57-0.95(0.05-2.05)$ & - & - & - & field & (Islam et al., 2004) \\
\hline & $0.57-0.69$ & - & - & - & field & (Rahman et al., 2006) \\
\hline \multirow[t]{2}{*}{ Canada } & 0.11 & 0.08 & 0.01 & 76 & market basket & (Heitkemper et al., 2001) \\
\hline & 0.02 & $<\mathrm{LOD}$ & 0.01 & 71 & - & (Williams et al., 2005) \\
\hline \multirow[t]{5}{*}{ China } & $0.14(0.02-0.46)$ & $0.16(0.07-0.38)$ & - & 87 & market basket & (Meharg et al., 2009) \\
\hline & $0.12(0.07-0.19)$ & - & - & - & - & (Williams et al., 2006) \\
\hline & $0.82(0.46-1.18)$ & $0.50(0.25-0.76)$ & $0.10(0.07-0.12)$ & $60(55-64)$ & - & (Sun et al., 2008) \\
\hline & $0.49(0.31-0.70)$ & - & - & - & Contam. field & (Xie and Huang, 1998) \\
\hline & 0.93 & - & - & - & Contam. field & (Liu et al., 2005) \\
\hline Egypt & $0.05(0.01-0.58)$ & - & - & - & - & (Meharg et al., 2009) \\
\hline Europe & $0.15(0.13-0.20)$ & $0.08(0.06-0.10)$ & $0.04(0.04-0.06)$ & $52(44-62)$ & - & (Williams et al., 2005) \\
\hline France & $0.28(0.09-0.56)$ & - & - & - & market basket & (Meharg et al., 2009) \\
\hline \multirow[t]{2}{*}{ India } & $0.07(0.07-0.31)$ & $0.03(0.02-0.07)$ & - & 43 & market basket & (Meharg et al., 2009) \\
\hline & $0.05(0.03-0.08)$ & $0.04(0.02-0.05)$ & $<$ LOD*$_{-0.01}$ & $56(36-67)$ & - & (Williams et al., 2005) \\
\hline
\end{tabular}




\begin{tabular}{|c|c|c|c|c|c|c|}
\hline \multirow[t]{2}{*}{ Italy } & $0.15(0.07-0.33)$ & $0.11(0.07-0.16)$ & - & 73 & market basket & (Meharg et al., 2009) \\
\hline & $0.21(0.19-0.22)$ & $0.12(0.10-0.14)$ & $0.07(0.05-0.09)$ & 57 (53-65) & - & (Williams et al., 2005) \\
\hline Japan & $0.19(0.07-0.42)$ & - & - & - & market basket & (Meharg et al., 2009) \\
\hline Philippines & $0.07(0.00-0.25)$ & - & - & - & - & (Williams et al., 2006) \\
\hline \multirow[t]{3}{*}{ Spain } & $0.20(0.05-0.82)$ & - & - & - & market basket & (Meharg et al., 2009) \\
\hline & $0.34(0.29-0.41)$ & $0.14(0.10-0.20)$ & - & $41(34-48)$ & market basket & (Laparra et al., 2005) \\
\hline & $0.17 \pm 0.01$ & 0.08 & 0.05 & 48 & - & (Williams et al., 2005) \\
\hline \multirow[t]{3}{*}{ Thailand } & $0.14(0.01-0.39)$ & - & - & - & market basket & (Meharg et al., 2009) \\
\hline & $0.10(0.06-0.14)$ & - & - & - & - & (Williams et al., 2006) \\
\hline & $0.11 \pm 0.01$ & 0.08 & 0.03 & 74 & - & (Williams et al., 2005) \\
\hline \multirow[t]{5}{*}{ Taiwan } & 0.76 & 0.51 & 0.11 & 67 & - & (Schoof et al., 1998) \\
\hline & $0.05(<0.10-0.14)$ & - & - & - & shed & (Lin et al., 2004) \\
\hline & $0.10(<0.10-0.63)$ & - & - & - & market basket & (Lin et al., 2004) \\
\hline & $0.19(0.06-0.17)$ & 0.12 & 0.04 & 61 & open & \multirow{2}{*}{ (Schoof et al., 1998) } \\
\hline & $0.20(0.19-0.22)$ & 0.11 & 0.05 & 58 & farm & \\
\hline \multirow[t]{4}{*}{ U.S.A. } & $0.25(0.03-0.66)$ & $0.10(0.05-0.15)$ & - & 40 & market basket & (Meharg et al., 2009) \\
\hline & $0.30(0.2-0.46)$ & - & - & - & market basket & (Schoof et al., 1999) \\
\hline & $0.28(0.21-0.34)$ & $0.10(0.02-0.11)$ & $0.18(0.17-0.24)$ & $35(9-32)$ & - & (Heitkemper et al., 2001) \\
\hline & $0.26(0.11-0.40)$ & $0.08(0.02-0.14)$ & $0.14(0.04-0.26)$ & 35 (10-61) & market basket & (Williams et al., 2005) \\
\hline \multirow{7}{*}{$\begin{array}{l}\text { Vietnam } \\
\text { West Bengal } \\
\text { (India) }\end{array}$} & $0.21(0.03-0.47)$ & - & - & - & open & (Phuong et al., 1999) \\
\hline & $0.14(0.02-0.40)$ & - & - & - & household & (Pal et al., 2009) \\
\hline & 0.25 (0.14-0.48)- boro & - & - & - & household & (Pal et al 2009) \\
\hline & $0.08(0.03-0.16)-a m a n$ & 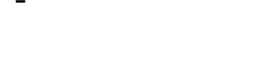 & - & - & (contam. area) & (Pdl el d., 2009) \\
\hline & $0.13(0.02-0.17)$ & - & - & - & field, market & (Mondal and Polya, 2008) \\
\hline & $0.21(0.11-0.44)$ & & & & household & לרחל \\
\hline & $0.33(0.18-0.43)$ & 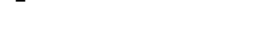 & 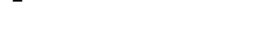 & - & (contam. area) & (Roychowahury et al., 2002) \\
\hline
\end{tabular}


860 Table 2: Arsenic concentrations ( $\mu \mathrm{g} \mathrm{g}^{-1} \mathrm{~d}$. wt.) in raw and cooked rice from different countries, and the contribution of arsenic concentration in cooking water on total and inorganic arsenic content in cooked rice

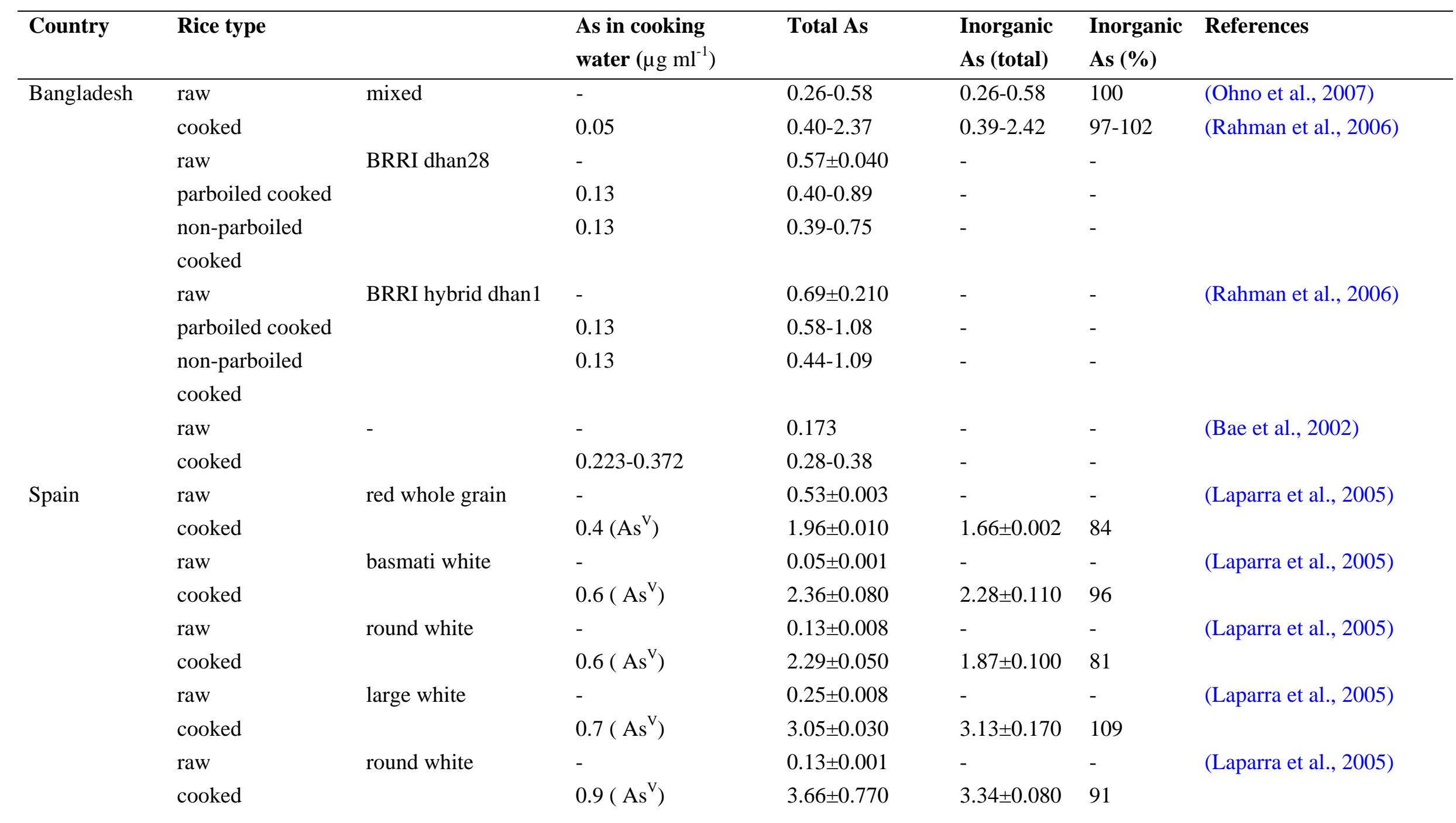




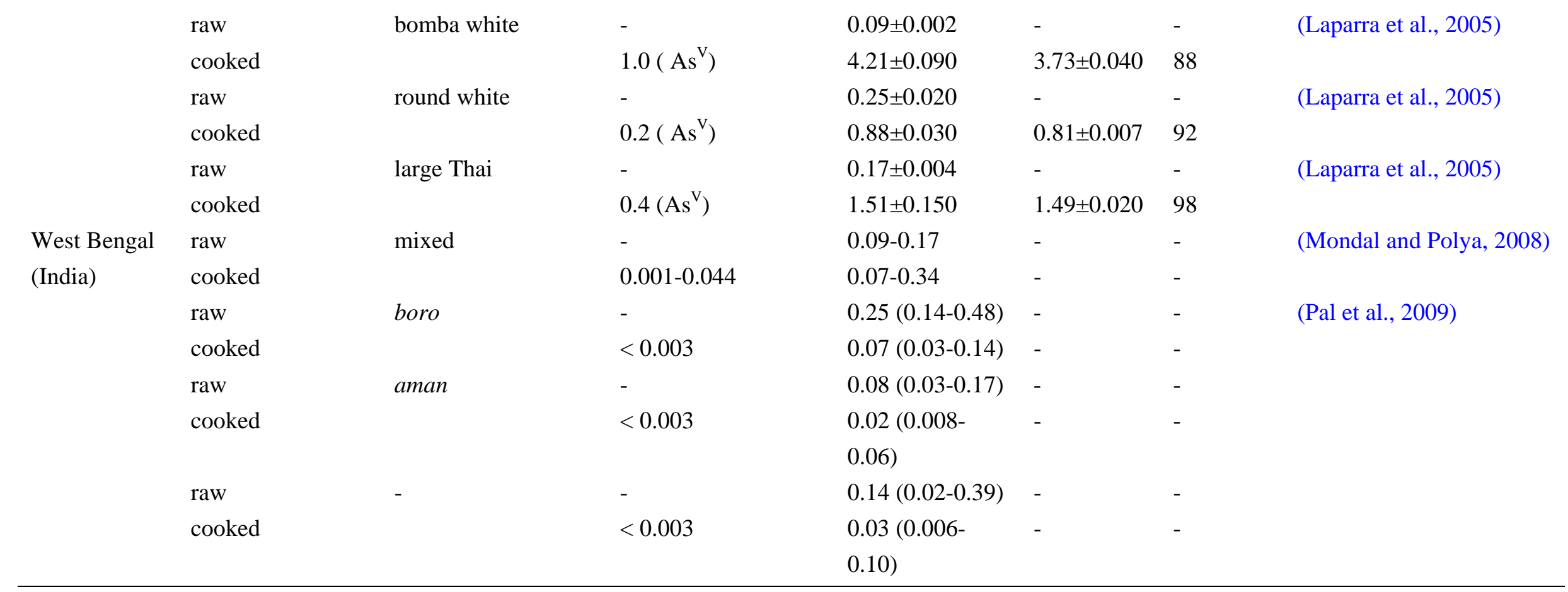

862

863 
Table 3: Total and inorganic arsenic concentrations ( $\mu_{\mathrm{g} \mathrm{g}} \mathrm{g}^{-1} \mathrm{~d}$. wt.) in rice grain, and the contribution of inorganic arsenic to the WHO’s provisional

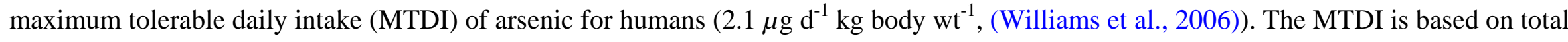

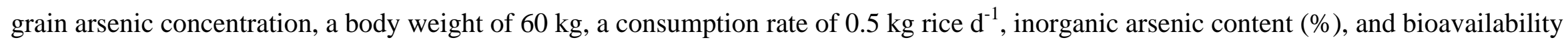
of inorganic arsenic in cooked rice (90\% (Laparra et al., 2005)).

\begin{tabular}{|c|c|c|c|c|c|c|}
\hline Country & Rice type/variety & Total As & Inorganic As & $\begin{array}{l}\text { Inorganic } \\
\text { As (\%) }\end{array}$ & $\begin{array}{l}\text { Contribution of inorganic } \\
\text { As to MTDI (\%) }\end{array}$ & \\
\hline \multicolumn{7}{|c|}{ Bangladesh } \\
\hline & BRRI dhan10 & $0.31 \pm 0.02$ & $0.22 \pm 0.02$ & 71 & 79 & (Williams et al., 2006) \\
\hline & BRRI dhan11 & $0.21 \pm 0.00$ & $0.14 \pm 0.02$ & 66 & 48 & (Williams et al., 2006) \\
\hline & Kalizira (local variety) & $0.18 \pm 0.03$ & $0.11 \pm 0.03$ & 60 & 38 & (Williams et al., 2006) \\
\hline & BRRI dhan28 & $0.25 \pm 0.00$ & $0.21 \pm 0.02$ & 83 & 74 & (Williams et al., 2006) \\
\hline & BRRI dhan29 & $0.21 \pm 0.01$ & $0.17 \pm 0.02$ & 82 & 62 & (Williams et al., 2006) \\
\hline & Nayanmoni (local variety) & $0.27 \pm 0.02$ & $0.22 \pm 0.03$ & 81 & 79 & (Williams et al., 2006) \\
\hline & Digha & $0.21 \pm 0.04$ & $0.15 \pm 0.04$ & 72 & 55 & (Williams et al., 2006) \\
\hline & Mixed & 0.39 & 0.39 & 100 & 139 & (Ohno et al., 2007) \\
\hline & Mixed & 0.13 & 0.08 & 61 & 29 & (Meharg et al., 2009) \\
\hline & Mixed & 0.13 & 0.08 & 60 & 29 & (Williams et al., 2006) \\
\hline & Mixed & 0.69 & 0.31 & 44 & 111 & (Sun et al., 2008) \\
\hline \multirow[t]{2}{*}{ Canada } & - & 0.11 & 0.08 & 76 & 26 & $\begin{array}{l}\text { (Heitkemper et al., } \\
\text { 2001) }\end{array}$ \\
\hline & - & 0.02 & 0.01 & 71 & 4 & (Williams et al., 2005) \\
\hline China & Long grain & $0.22 \pm 0.03$ & $0.07 \pm 0.01$ & 32 & 25 & (Williams et al., 2006) \\
\hline Europe & - & 0.15 & 0.08 & 52 & 29 & (Williams et al., 2005) \\
\hline \multirow[t]{2}{*}{ India } & - & 0.07 & 0.03 & 43 & 11 & (Meharg et al., 2009) \\
\hline & - & 0.05 & 0.04 & 56 & 14 & (Williams et al., 2005) \\
\hline \multirow[t]{2}{*}{ Italy } & - & 0.15 & 0.11 & 73 & 39 & (Meharg et al., 2009) \\
\hline & - & 0.21 & 0.12 & 57 & 43 & (Williams et al., 2005) \\
\hline
\end{tabular}




\begin{tabular}{|c|c|c|c|c|c|c|}
\hline \multirow[t]{8}{*}{ Spain } & Red whole & 1.96 & 1.66 & 84 & 85 & (Laparra et al., 2005) \\
\hline & Basmati white & 2.36 & 2.28 & 96 & 97 & (Laparra et al., 2005) \\
\hline & Round white & 2.29 & 1.87 & 81 & 82 & (Laparra et al., 2005) \\
\hline & Large white & 3.05 & 3.13 & 109 & 103 & (Laparra et al., 2005) \\
\hline & Round white & 3.66 & 3.34 & 91 & 91 & (Laparra et al., 2005) \\
\hline & Bomba white & 4.21 & 3.73 & 88 & 89 & (Laparra et al., 2005) \\
\hline & Round white & 0.88 & 0.81 & 92 & 92 & (Laparra et al., 2005) \\
\hline & Large Thai & 1.51 & 1.49 & 98 & 99 & (Laparra et al., 2005) \\
\hline Thailand & - & 0.11 & 0.08 & 74 & 29 & (Williams et al., 2005) \\
\hline \multirow[t]{3}{*}{ Taiwan } & - & 0.76 & 0.51 & 67 & 182 & (Schoof et al., 1998) \\
\hline & - & 0.19 & 0.12 & 61 & 43 & (Schoof et al., 1998) \\
\hline & - & 0.20 & 0.11 & 58 & 39 & (Schoof et al., 1998) \\
\hline \multirow[t]{3}{*}{ USA } & - & 0.25 & 0.10 & 40 & 36 & (Meharg et al., 2009) \\
\hline & - & 0.28 & 0.10 & 35 & 36 & $\begin{array}{l}\text { (Heitkemper et al., } \\
\text { 2001) }\end{array}$ \\
\hline & - & 0.26 & 0.08 & 35 & 29 & (Williams et al., 2005) \\
\hline
\end{tabular}



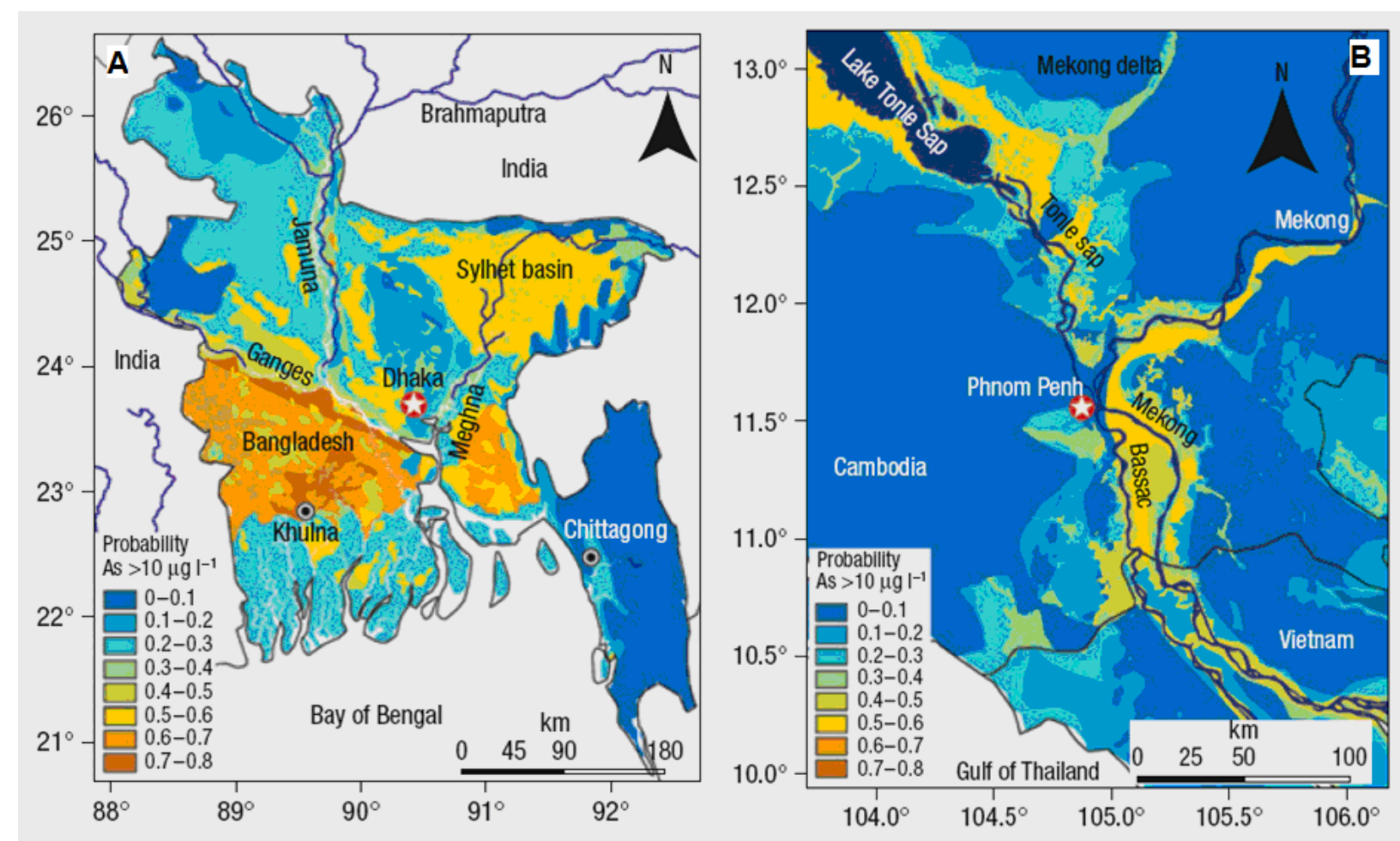

878
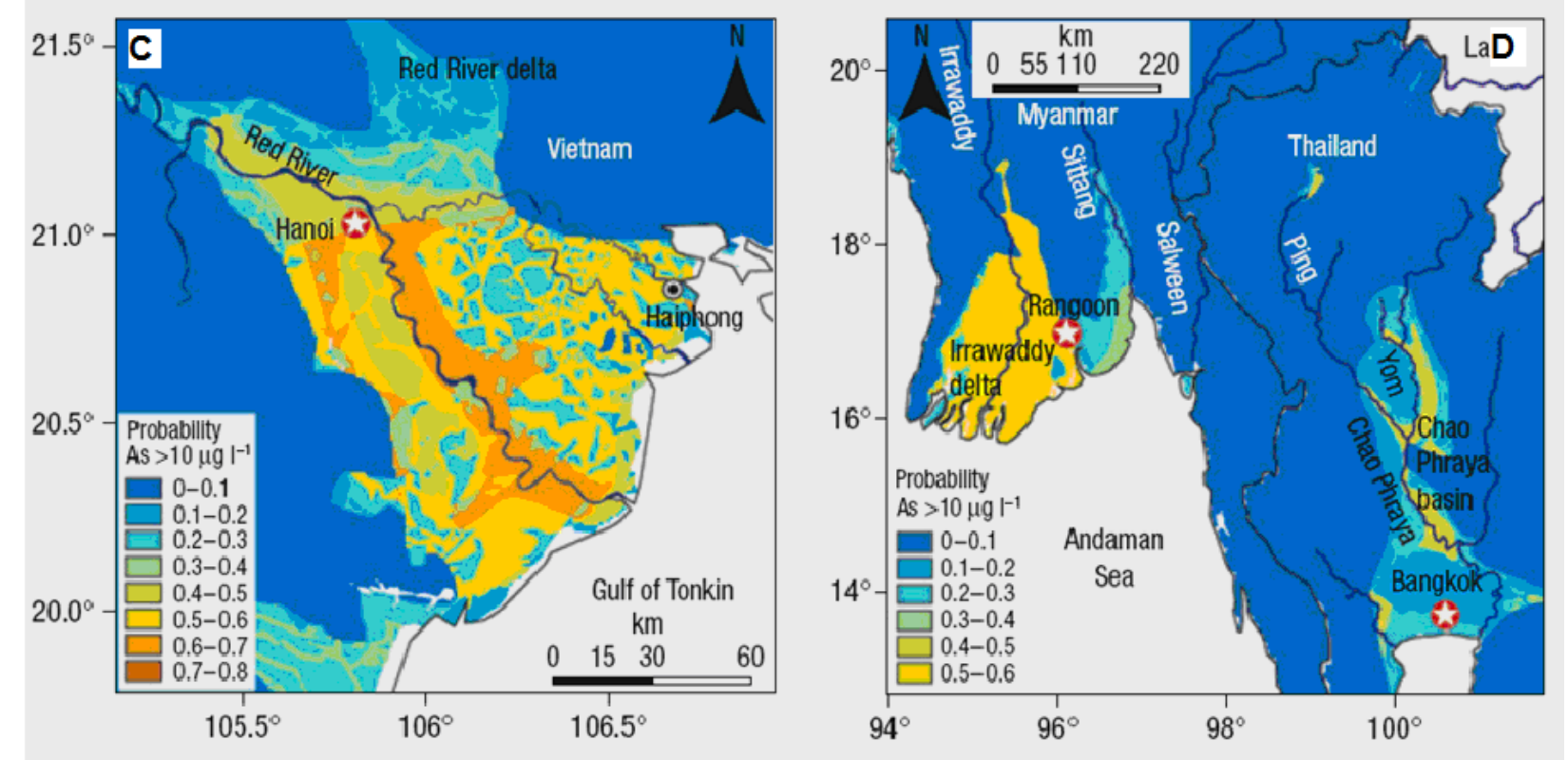

879 Fig. 1: Arsenic concentrations in groundwater of South-East Asian regions under reducing conditions. A, Ganges delta (Bangladesh); B, the Mekong delta (Cambodia and Vietnam); C, Red River delta (Vietnam); D, Irrawaddy River delta (Myanmar) and Chao Phraya basin (Thailand) (Winkel et al., 2008). 